Karin Stoll

Nord University

Mette Gårdvik

Nord University

Wenche Sørmo

Nord University

DOI: https://doi.org/10.5617/adno.8429

It is important that the others, that absolutely all schools in all countries and in Norway should of course receive a teaching [...] that they get to do practical tasks where they actually get to see how bad it is. That they get to see and learn what it is important for them to do in the future so that we do not destroy nature and the earth. (Student quote)

\title{
The role of the arts and crafts subject in education for sustainable development
}

\begin{abstract}
The article presents a qualitative study of the contribution of arts and crafts (AC) in an interdisciplinary teaching project on marine litter in Norway. We explain how the subject AC may contribute in education for sustainable development beyond competence goals described in the new Norwegian curriculum "Fagfornyelsen" (LK20), where the focus is on technological competence and knowledge of materials, recycling and product development. The empirical data consist of notes from participatory observation and visual expressions from students in grades $5-10$. We used the Visual Art Based Participatory Method to analyse the material. The results indicate that creative and making processes in AC are important in giving students the opportunity to express and process their feelings about difficult dilemmas, and this seems to be an important contribution to increase students' understanding, commitment and action competence for sustainable development. Through Eco Art, students contributed to the societal debate and gained insight into society's conflicts of interest. We believe that physical learning opportunities and the affective element in AC is under-communicated in LK20, but that it is crucial for students' motivation to learn and act for a sustainable future. With this article we hope to open a discussion in the field about AC's role in education for sustainable development.
\end{abstract}

Keywords: arts and crafts, education for sustainable development, affects and emotions, Art Based Method, Norwegian curriculum "LK20”, marine litter 


\title{
Kunst og håndverksfagets rolle i utdanning for bærekraftig utvikling
}

\begin{abstract}
Sammendrag
Artikkelen presenterer en kvalitativ undersøkelse om kunst og håndverksfagets bidrag i et tverrfaglig undervisningsprosjekt om marin forsøpling i Norge. Vi gjør rede for hvordan faget kunst og håndverk bidrar i utdanning for bærekraftig utvikling utover kompetansemål beskrevet i de nye norske læreplanene, LK20, der fokuset er på teknologisk kompetanse og materialkunnskap, gjenbruk og produktutvikling. Empirien består av notater fra deltakende observasjon og visuelle uttrykk fra elever på mellomtrinnet og ungdomstrinnet. Vi benyttet Visual Art Based Participatory Method for å analysere materialet. Resultatene indikerer at kreative og skapende prosesser i kunst og håndverk er betydningsfulle for å gi elevene mulighet til å uttrykke og bearbeide sine følelser om vanskelige dilemma. Dette ser ut til å være et viktig bidrag for å øke elevenes forståelse, engasjement og handlingskompetanse for bærekraftig utvikling. Gjennom Eco Art bidro elevene til samfunnsdebatten og fikk innblikk i samfunnets interessekonflikter. Vi mener at det kroppslige og affektive elementet av kunst og håndverksfaget er underkommunisert i LK20, men at det har avgjørende betydning for elevenes motivasjon for å lære og handle for en bærekraftig fremtid. Med denne artikkelen ønsker vi å åpne opp for en diskusjon i fagfeltet om kunst og håndverks rolle i utdanning for bærekraftig utvikling.
\end{abstract}

Nøkkelord: kunst og håndverk, utdanning for bærekraftig utvikling, følelser, Art Based Method, Fagfornyelsen LK20, marin forsøpling

\section{Introduction and background}

Today's and future generations face enormous environmental challenges. Marine litter is one of the biggest global environmental challenges (UNEP, n.d.) and affects both ecosystems, human health and economy (UNEP, n.d.; Miljødirektoratet, n.d.). Large amounts of waste are visible along the coast in our environment. Plastic is made to last, then crumbles into ever smaller pieces and enters food chains. With this background, we developed the project "Sea monsters - Marine litter as a teaching resource” (Gårdvik et al., n.d.).

Focusing on education for sustainable development (ESD) with science and arts and crafts (AC), students at grades 5-10 work exploratively within science activities. A key element is to develop students' ESD competences (Mogensen \& Schnack, 2010; Sinnes, 2015) through aesthetic-creative processes (Figures 1, 2). Students were given a task about drawing their thoughts, ideas and experiences related to marine litter. Each class created a common garbage sculpture on the local beach to be exhibited in their community. 

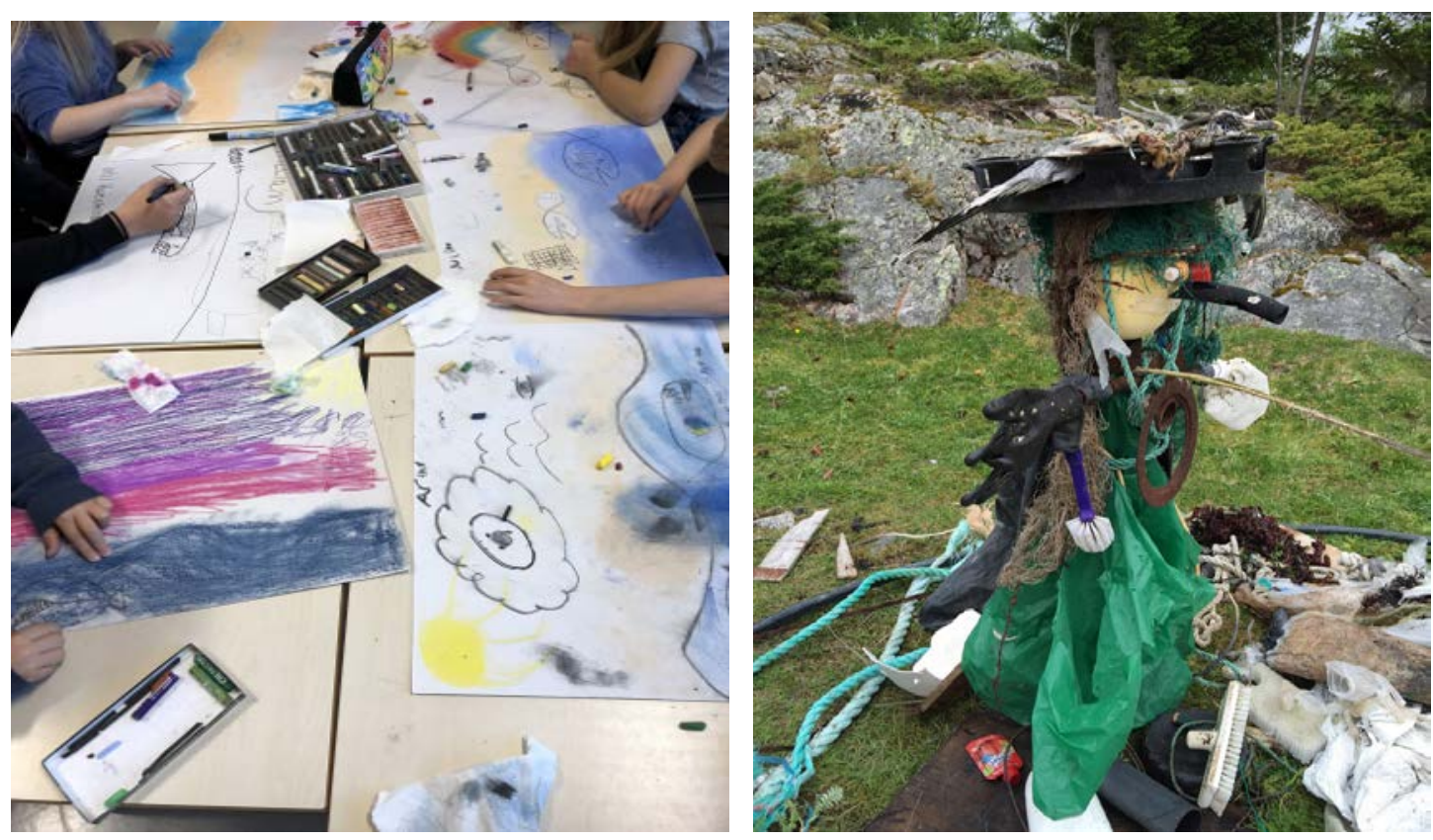

Figure 1. Students working on drawings.

Figure 2. The sculpture is made of marine litter collected in the coastal zone. The students found a dead seagull that was placed as a crown on top of the sculpture and conveys "death that all the litter brings".

Photos: Mette Gårdvik

Objectives in the project are:

- Give the participants ownership of the problem, as well as vision and skills to be able to improve the situation

- Allow students to express themselves through individual drawings and community-based sculptures

- Communicate the problem to the local community and increase engagement through Ecological Art (Eco Art)

The project is described in detail in Stoll et al. (2018) and analysed in relation to ESD (Sinnes, 2015, p. 51) in Sørmo et al. (2018).

\section{Education for sustainable development}

In the wake of the UN's decade of ESD, educational systems have focused on the topic (UNESCO, 2005, 2015) to provide solutions to global environmental and economic problems. Emphasis is placed on participation, inclusion, risk awareness and effective value discussions (UN, 2015).

Research provides guidelines for sustainable development (SD) teaching, based on complex issues that include social, economic and environmental perspectives (Breiting \& Mogensen, 1999; Breiting, 2011; Kopnina, 2012, 2014; Mogensen \& Schnack, 2010; Olsson et al. 2016; Sinnes, 2015; Turmo \& Østergaard, 2011; Wals, 2012). 
Öhman (2006) proposes a pluralistic approach to ESD to bring out different perspectives and values where students discuss authentic challenges. The UN's Sustainability Goals (UNESCO, 2015) emphasise that many challenges have a technological or scientific nature (Sinnes \& Jegstad, 2011; Sundberg \& Ottander, 2014; Turmo \& Østergaard, 2011). Understanding challenges and opportunities associated with SD requires knowledge of the sources of these problems and how they affect us. ESD highlights six key competences as particularly important: critical thinking, creativity, collaboration, system understanding, action competence, and future thinking (Mogensen \& Schnack, 2010; Sinnes, 2015, 2020; Stevenson et al., 2013; UNESCO, 2015). Sinnes (2020) points out that students should experience that their actions are important by working exploratively and creatively, finding solutions to complex problems, and gaining experience in influencing their school and community. Students need in-depth knowledge related to action, and ecological literacy (Lutnæs \& Fallingen, 2017).

Sinnes and Straume (2017), Kvamme and Sæther (2019), Lutnæs and Fallingen (2017), and Näumann et al. (2020) discuss whether SD presents an anthropocentric view of the concept of sustainability and suggests that it should be used in a post-humanist perspective in teaching.

The Norwegian Centre for Science in Education has contributed to the preparation of a Nordic model for ESD (Scheie \& Korsager, 2017). Through the project "The Sustainable Backpack", they had a national responsibility for research-based development of didactics and implementation of ESD in all subjects (Scheie \& Stromholdt, 2019; Korsager \& Scheie, 2019; see also www.natursekken.no). The goal is to increase students' knowledge and awareness of SD and the environmental challenges, and be able to develop solutions to environmental problems.

SD is one of three interdisciplinary thematic areas emphasised in the overall part of the new Norwegian curriculum (LK20) (Report to the Parliament 28, KD, 2016, p. 39; Udir, 2020) and states that education shall facilitate students' belief in, and acknowledgment of, their responsibility for active and conscious action for a sustainable future. The goal is to understand dilemmas including social, economic and environmental and developmental features in society. Teaching is related to UN's sustainability goals (UN, 2015). Competence goals for interdisciplinary teaching within SD are found in most school subjects. Technology has a central role, but this is criticised by Sinnes and Straume (2017) and perceived as a focus on a techno-optimistic sustainability perspective that could be in tension with the responsibility each individual has to act for a sustainable future. 


\section{Arts and crafts and ESD anchored in research}

Research emphasises that AC is a well suited competence builder due to anchoring in specific working methods, flexible results and the ability to give students ownership of their education (Solheim, 2009). AC can contribute to create a good social environment characterised by security, well-being and mastery. This lays the foundation for an increased level of function in students and creates positive learning opportunities (Johansson, 2019). In Norway, the Report to the Parliament 28 (KD, 2016, p. 48) highlights the practical aesthetic subjects and points out that each has justification and anchoring in various academic disciplines:

The practical nature of the subjects can contribute to them differing from learning and working methods in other school subjects, but the subjects should not be an escape for making the school less theoretical for the students. (Our translation)

According to Lutnæs and Fallingen (2017), AC in ESD can contribute to ecoliteracy including awareness and change competence through practical creative work, aesthetic experience, responsible product development and critical reflection. Lutnæs (2015) points out that when many individuals change their patterns of action and thought, critical reflection can lead to system changes - like transformation of consumer culture and market mechanisms (Lutnæs, 2015, p. 8).

In LK20, technological competence and knowledge of the connections between technology and the social, economic and environmental perspectives of SD are central in AC. Emphasis is placed on product development, material knowledge and re- and up-cycling (Udir, 2020). We find five bullet points with competence goals in AC connected to SD, but these deal with repair, material use and recycling. With goodwill, we find only 3 out of a total of 41 competence goals that could connect to SD: After 7th grade, students should explore how emotions and opinions are displayed in art, and use symbolism and colour to express opinions in their work. After 10th grade, students must analyse how identity and place belonging are communicated in architecture, clothing traditions, art or objects, and integrate cultural references in their creative work. In addition, they shall investigate how art can contribute to social criticism, and create art expressions that shed light on challenges.

The interdisciplinary perspective is lacking in AC, and bears little mark of the responsibility and opportunities that lie in the practical aesthetic subjects to strengthen students' self-confidence and sense of mastery (Koritzinsky, 2021).

Näumann et al. (2020) present how they believe in working with sustainability in AC and propose didactics that have strong focus on re- and upcycling and sustainable material use. Their goal for AC is to function as a unifying force where creative and artistic dimensions are included on an equal level with the technical and social science dimensions in ESD, and they criticise how SD is downplayed in AC's curriculum. They rely on Sinnes and Straume (2017) and state that 
formulations in the curriculum have a conflicting view of sustainability when the technically rational and human-centric perspectives in technological product development are connected with ethical and existential questions about human life. The concept of competence distinguishes between cognitive knowledge and practical skills and this is ill-suited in sustainability didactics where competences are in a dynamic interplay between cognitive understanding and the practicalbodily doing. Furthermore, they criticise that concepts such as mastery and perseverance instrumentalises AC to enhance technology, and claim that the professional depth makes it difficult to realise interdisciplinary breadth, which is essential for a holistic sustainability didactics. The schemes that are presented and proposed in their book for teaching sustainability didactics in AC (Näumann et al., 2020) are, as we see it, of a mainly monodisciplinary nature.

The research network SILAS (Sloyd, Education, Learning and Sustainability) with Ahlskog-Björkman et al. (2020) has explored Nordic craft educators' attitudes to SD and looked at how craft education can contribute to SD. SILAS has interviewed eight Nordic craft educators. Results show that the main focus in craft teaching is largely related to material knowledge, and to some extent the emotional aspect in the face of materials. This can contribute to the craftsman changing his attitudes to production and consumption through compassion and may change the practitioner's human-centred lifestyle.

Johansson (2019) states that handicraft knowledge can largely be related to SD and discusses how it, with its material and cultural immaterial resources, can take care of SD in professional management documents and the UN's sustainability goals. She criticises that the opportunity for SD in AC is minimally maintained as an independent focus area in research, and is rather connected as an addition to other starting points like classroom research, materiality and gender.

On the research front and in curriculum the role of AC, in relation to uncovering, meeting and processing the affective side of the ESD themes, has been omitted. The subject's role as a contributor developing students' identity, commitment and well-being in a cultural sustainability perspective is little discussed. The same applies to the subject's potential to contribute to public debate through visual expression and in this way develop students' action competence in ESD.

\section{Research question}

The study is a contribution to promote the discussion about whether the AC subject can have a more multifaceted significance in ESD than what is reflected in current research and the subject's competence goals in LK20. Our research question is: 
How can arts and crafts contribute to an interdisciplinary ESD project on marine litter, and what does this mean for AC's role in ESD?

To find answers, we used empirical data from our teaching project about marine litter.

\section{Theory}

\section{Cultural sustainability: Art and action}

Culture is dynamic and constantly changing. In this process, people can be innovative and influence the future with forward-looking ideas and values. Cultural sustainability is not mentioned explicitly as a sustainability perspective in the Nordic model for ESD (Scheie \& Korsager, 2017), but is included mainly in the social perspective. However, cultural sustainability is recognised as an equal perspective (Figure 3) and deals with people's relationships to each other and their attitudes towards local communities and the environment (Härkönen et al., 2018; Stoltenberg, 2020/2010; Soini \& Dessein, 2016).

\begin{tabular}{|c|c|}
\hline economic dimension & ecological dimension \\
\hline $\begin{array}{l}\text { preventive economic management, } \\
\text { regional and local marketing networks, } \\
\text { material flow management, } \\
\text { environmental management system, } \\
\text { environmentally friendly and } \\
\text { innovative technologies, } \\
\text { Eco-Design (disposal possibility, } \\
\text { duration of use, aesthetic), } \\
\text { ecological and socially fair prices, } \\
\text { costs-by-cause principle, } \\
\text { circular economy, } \\
\text { fairtrade }\end{array}$ & $\begin{array}{r}\text { environmental friendly procurements, } \\
\text { avoiding pollution of ecosystems, } \\
\text { sparse use of resources - saving } \\
\text { materials, energy and water, } \\
\text { re-use, recycling and sorting of waste, } \\
\text { regeneration possibilities of } \\
\text { ecosystems, } \\
\text { ecosystems and biodiversity, } \\
\text { ecological cycles, } \\
\text { regenerative energy, } \\
\text { green transport }\end{array}$ \\
\hline social dimension & cultural dimension \\
\hline $\begin{array}{l}\text { democratization, } \\
\text { promoting human health, } \\
\text { intra-social justice, gender equality, } \\
\text { equal rights using natural resources, } \\
\text { justice between generations, } \\
\text { taking into account the interests of } \\
\text { future generations, } \\
\text { participation and inclusion of all social } \\
\text { groups, } \\
\text { diversity of values, } \\
\text { livelihood through work }\end{array}$ & $\begin{array}{r}\text { ethical assurance, } \\
\text { identity and commitment, } \\
\text { traditional knowledge, } \\
\text { local cultural diversity, } \\
\text { creativity and recreation, } \\
\text { learning and exploration, } \\
\text { fair lifestyles in terms of sustainability, } \\
\text { holistic perception of nature, } \\
\text { aesthetic perception of sustainability, } \\
\text { conservation of cultural environment, } \\
\text { culture of dealing with time and } \\
\text { materials and local cultural traditions, } \\
\text { consumer awareness, } \\
\text { cosmopolitan culture, } \\
\text { global awareness }\end{array}$ \\
\hline
\end{tabular}

Figure 3. Cultural sustainability as an equal perspective in ESD. Translated and modified after Stoltenberg (2020/2010).

What has been created must be accounted for, and from a cultural sustainability perspective it is important that we create a relationship with the consumer culture. 
It is central to maintain and reflect on cultural beliefs and practices (e.g., consumption patterns and environmental practices) and to protect culture as a separate entity. In this discourse, one tries to find an answer to the question of whether our current cultures will be able to exist in the future (Soini \& Birkeland, 2014).

Cultural sustainability is site-specific, i.e., each locality must evaluate its needs, rights and responsibilities in order to live more sustainable lives (Härkönen et al., 2018). Experiencing culture, local environment and interactions between nature and people both before and now, can contribute to children becoming happy in both nature and culture. The place helps in building children's identity, and can lead them to feel a stronger sense of belonging and motivation to take care of the place by giving ownership to issues in their own community (Sørmo et al., 2019). Children need to experience the world in reality, also in teaching in the form of project-based and situated learning (Lave \& Wenger, 1991; Sinnes, 2015; Gårdvik et al., 2015; Jokela \& Coutts, 2018).

Didactics in AC has developed from being about teaching's how (individual skills training) to emphasising the interaction between school and society, past, present and future (Nielsen, 2009). LK20 for AC emphasises interaction between school and society in three interdisciplinary themes (KD, 2017). This reflects the paradigm shift in art education from an individual focus on artistic expression to a focus on the community where art contributes as a free dialogue with the society about challenges the world faces (Jokela \& Coutts, 2018; Härkönen et al., 2018). We see that the focus on cultural sustainability is also present in LK20 in AC:

AC is a key subject for practical skills, creativity and reflection on visual and material culture. By participating in aesthetic processes, students will gain experience in imagining what is not yet, and a basis for participating in cultural and social development. The subject will prepare students for an everyday and working life that demands innovation, practical skills and the ability to make aesthetic and ethical choices. Collaboration with local cultural and business life shall contribute to linking students' creative work to current issues. (Udir, 2020, our translation)

Artists have used Eco Art to work with ecological and social themes and have helped to change values and attitudes of public consciousness (Brenson, 2001; Thornes, 2008). Social Art Practice and Community Art are about empowering and liberating individuals and communities to achieve personal, social, cultural or political change. The purpose is to arouse emotions and create awareness and commitment in individuals and stimulate dialogue between people to change their behaviour to increase quality of life (Permar, 2019; Hiltunen, 2008; Austin, 2008). This is directly linked to the concept of "cultural dimension of sustainability" (Figure 3), which is about increased social interaction and sense of community in the local community, through collaboration (Illeris, 2017; Jónsdóttir, 2017).

The art educator Mantere (1995, p. 1) defined art-based environmental education as a form of learning with the aim of developing understanding and responsibility for the environment where the relationship between the individual and their environment is central. Her research shows that sensitivity to the 
environment can be developed through artistic activities. Innovative people with the ability to work interdisciplinary prove to be adaptable and creative problem solvers. It is important that students have the opportunity to practice these skills through education (Coutts, 2013; Eisner, 2002). Community and Eco Art are creative learning arenas that generate new understanding and insight and help students to develop belonging to their environment and provides knowledge and experience about local materials and culture (Gårdvik, 2011; Van Boeckel, 2013). According to Eisner (2002), children will learn that a problem can have more than one solution and a question can have more than one answer in the arts.

\section{AC and ESD and the bodily-emotional aspect}

Østern and Dahl (2019, p. 34) rely on Massumi's (1995) description of affect not as comprehensible emotions, but intensities in the body based on a physiological response to an event that can initiate autonomous processes. Affects thus act directly and independently of the brain's reflection or need to put into words, and represent effects inside the body that are not yet pronounced and understandable emotions. Emotions are a reaction to an affective influence that has been treated cognitively by the brain so that it has a more lasting effect that can be expressed and change our behaviour.

People need to experience beauty in nature to develop positive emotions, but this alone is not enough to trigger actions for a sustainable future that involves moving from a selfish to a solidary behaviour. Research shows that emotions such as empathy and fear of the future are important for motivating students to take action and trigger hope (Ojala, 2007, 2013; Persson et al., 2011; Kielland, 2021).

ESD has a strong affective side that triggers both spontaneous affects and emotions. To visualise this, we have added two dark blue arrows to Figure 4 to show that affective perspectives play a central role when students encounter emotional and complex topics. Attitudes like belief in opportunities, hope for the future and motivation to act are also strongly influenced by emotions. In research studies concerning ESD, the emotional dimension such as hopelessness, passion and dissonance are often mentioned (Wals, 2015; Sund \& Öhman, 2014), but not given enough attention in ESD competences. Ojala $(2013,2017)$ criticises that ESD pays little attention to the emotional aspect and that this can hinder students' learning, action, hope and visions for the future. She emphasises the importance of students gaining knowledge about how they can deal with emotions constructively in order to get motivated to act within SD. It is a key skill that the students had to accomplish working with SD problems, and we added this competence to Figure 4 (a dark blue textbox). This presupposes that teachers must also have knowledge of the significance of emotions for learning (Kielland, 2021), and that this in turn is related to how students' emotions are handled in a teaching situation. 


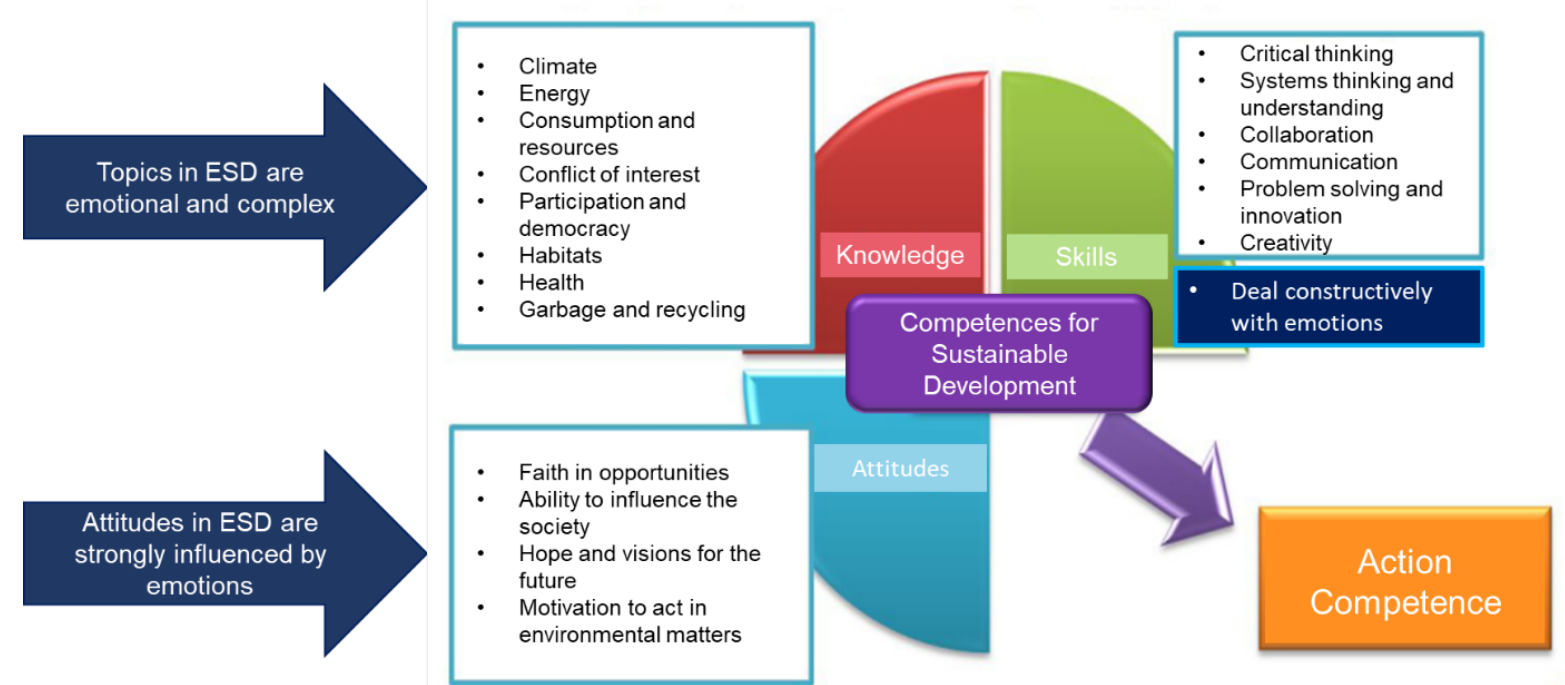

Figure 4. Affective components in ESD are marked with dark blue arrows and a textbox, and added to the original figure of Mogensen and Schnack (2010) visualising ESD competences. Working with ESD topics confronts the students to deal with complex and emotional dilemmas without any "right" or "wrong" answers. Attitudes which should be developed in ESD are strongly influenced by emotions.

Research from Folkman (2009) and Ojala (2013) also indicates that the way students master emotional challenges depends on teaching facilitating interaction, processing and communication. According to Bradshaw (2010), verbal language is a poor medium for communicating emotional nuances. Frisch (2013), Van Manen (1990) and Hopperstad (2005) have shown that visual expressions are a language that can provide insight into children's emotional world. Art opens up for unconscious feelings and thoughts to be given a physical expression. Lowenfeld and Brittain (1976) state that drawing can support young people's development of agility, originality and imaginative thinking, in addition to helping them to grow emotionally, express themselves and cope with new situations. Without appearing as a therapist, an AC teacher can give students opportunity to express themselves artistically about possible fears for the future, and at the same time process emotions in a safe environment and thus act therapeutically. Mantere (1992, p. 23) mentions the use of visual expressions that promote personal thoughts about environmental challenges:

It is a therapeutic act to receive these images with respect for the students' inner view of the world, but at the same time try to convey a positive attitude to life and give them hope for the future.

Having faith in the future and developing attitudes for SD is a prerequisite for students to want to act in a sustainable way. This is important for students' choices and thus for the individual's future. In his research, Damasio (2000) points out from a neuro-scientific perspective that our emotions are essential in relation to development of attitudes and belief in the future, and that physiological processes pave the way for what happens in the brain. Therefore, the affective and bodily, sensory, relational and creative parts of learning are important elements in ESD. 
In the same way as Dahl and Østern (2019, p. 51) describe processes that promote depth//learning, ESD is about having the body on the team and getting it to produce those affects and emotions that motivate, inspire and demand to make students want to learn.

In AC education, aesthetic and bodily learning with all senses is essential (Dewey, 2005/1934; Eisner, 2002). Aesthetic competences are a source of development on several levels from personal growth via influence from one's local community to creative innovation in a larger perspective (Coutts, 2013; Gårdvik, 2010). Also in ESD are these working methods important, and creativity is mentioned as a key skill (Korsager \& Scheie, 2014). Creativity, on a cognitive level, is a key factor in being able to understand systems and contexts. Creativity is also important when knowledge is to be transferred to and used in other contexts, which characterises the concept of in-depth learning in the curriculum renewal in Norway (NOU 2015: 8, p. 49; Sinnes \& Straume, 2017, p. 13; Udir, 2019). It is not explained whether creativity in this context is intended as a cognitive, an innovative and formative, or a physical skill, but the emphasis on the cognitive side of creativity seems to be most prominent (Dahl \& Østern, 2019).

Fredriksen (2013) refers to Eisner (2002) to justify that AC as an aesthetic subject, to a greater extent than other school subjects, safeguards children's holistic learning. AC can be a safe arena for students to critically explore and experience cultural and ecological problems that affect their own lives and futures (Milbrandt, 2002). Østergaard (2013, p. 15) says about ESD competences:

Admittedly, basic science knowledge plays an important role here, but when the task is to facilitate that students can connect with the world, more than knowledge is needed. What we need is an education that meets the world, that facilitates rich, aesthetic experiences, and that enables and develops the diverse relationships we have with the world. In order to achieve this goal, both the natural sciences and the arts in the school, however different they may be, must move in the same direction.

\section{Method}

In this qualitative study, we analysed empirical data from our teaching project about marine litter with all 12 school classes from grades 5-10 within the project area. The schools were located along a fjord on the coast of Northern Norway, where marine resources are important prerequisites for settlement and industry. The empirical data consist of 62 individual student drawings and 12 Eco Art sculptures where process and product were documented using participatory observation and photography. We carried out the project ourselves in the same way in the participating schools. To bring out the participants' voices, we used direct quotes from dialogues that arose between students in the drawing process, as suggested by Creswell (2013, p. 19). Statements were written down by hand during the teaching, and were anonymised as part of our observation notes. 
We used Visual Art Based Participatory Method (VABPM) to get insight into the participants' feelings and complex opinions, such as thoughts and ideas about marine litter, articulated through students' visual expressions. In this way, participants represent a duality in relation to empirical data in that they themselves are part of the study at the same time as they produce data in the form of visual expressions that are analysed (Leavy, 2015, p. 232). Leavy (2015, p. 271) presents various creative strategies for use in analyses of visual expressions to translate them into words based on Manders and Chilton (2013). In our analysis, we used free association and creative dialogue as creative strategies within Artistic Inquiry Translation to interpret participants' artistic expression. Both strategies were used when in the analysis one moves between artistic expression and text, i.e., when artistic expressions were to be described also in text form. In free association, we as researchers put into words the first thing we think of when we look at the visual expression. We three went through the visual expressions for ourselves and wrote down what we immediately saw. With this as a starting point, we have roughly sorted the expressions, such as fish, human activity, rubbish, sun, mountains, beach and more. After this process, we compared our individual data and created categories such as animals, animals that suffer, garbage collection, death and more. To get to the final and overall categories, we went further into a creative dialogue and "interviewed" the visual expressions in several rounds using the form of a direct dialogue to gain access to unconscious messages or knowledge. In the connotative sorting, we focused on the drawings and the sculptures' messages (Samuelsen, 2013). In this context, we did not focus on children's drawings and sculptures as a genre or analysed them according to artistic qualities, but looked at what they told us about students' thoughts, experiences and understanding of marine litter. Categories became clear and the material could be grouped by content and message. After our discussions, we came to the final categories: a nice world, experiences with marine litter, empathy with animals, system understanding, faith and hope for the future, and symbolism related to death.

\section{Ethical considerations and validity}

Creswell (2013, pp. 57-58) states that ethical considerations must be taken seriously in all parts of a study, especially when children are involved. We have informed students, parents, teachers and school leaders about collecting data from the teaching project, including public exhibitions, and about the main goal for the following research, orally and in written text. The participants were also given information that their participation was voluntary. The consents gave us permission to use observations, visual artworks, and quotes as research material in publications. The empirical material in our research is anonymised and any signs of personal identifications are removed. The study is limited in time, space and scope, and the results are valid for this research only. We can nevertheless claim that our findings about the AC subject's role in ESD should contribute to a greater 
focus and discussion about the importance of AC in interdisciplinary teaching of ESD.

\section{Results}

\section{Observations from drawing and sculpting processes}

The majority of students were eager and thought it was exciting to draw with pastel chalk. Some went into a "bubble" where deep concentration and attention were directed towards the drawing. Some other students thought it was unusual to draw with pastel chalk and needed some training. Others wondered if they were really allowed to use their fingers to mix colours and make transitions and were busy exploring materials and technique. Others preferred to use pencil because they thought drawing with chalk was not detailed enough in relation to what they wanted to produce. We also observed that students began to talk and share their experiences about environmental issues while drawing.

Down on the shore, students showed great commitment in looking for litter. The litter consisted of various materials, mostly plastic. Students eagerly talked about where the waste came from, and were motivated to explore this further in the project's follow-up. Sculptures built by students were characterised by the amount and type of material they found. We use the term "sculpture", although several of the expressions cannot be defined within this art form. Some school classes focused on using all the litter they found (Figures 9, 10), while others had more focus on the aesthetics of the expression, working consciously with material and place (Figure 6). Several chose to build in a message to the outside world, such as compassion (Figures 13,19), and symbolism related to death and danger (Figures 2, 22), but also hope for the future (Figure 19) in that together people can do something about the problem.

In many conversations between students, it was clear that the experience of picking up rubbish on the beach was crucial for them to understand the extent of the problem. Students said: "There was a lot more rubbish than I thought, there was a lot we found that you did not expect to find on the shore", and "No, we need to see with our own eyes, how much litter there really is." Another student shared feelings: "I think if we do something about it out there then we know how it feels." In all school classes, there were some students who were not particularly engaged in working on assignments within the topic.

\section{Content and expression in the children's drawings and sculptures}

In the analysis of the children's expressions, we came to the following categories: a nice world, experiences with marine litter, empathy with animals, system understanding, faith and hope for the future, and symbolism related to death. Some drawings and sculptures may fit into several categories but we have placed them after, for us, the most prominent message. From a total of 62 students, 10 
students did not draw or made a mess and these drawings were not included in the VABPM analysis. Of the 52 analysed drawings, there were 3 drawings that did not contain anything about the topic marine litter. All 12 sculptures were built by materials from marine litter that participants themselves cleared from beaches and were thus involved in the analysis.

\section{Category 1: A nice world}

We have selected visual expressions that convey joy related to their hometown (Figures 5, 6). We interpret from these expressions that children reflect on the landscape they live in and that they feel good about a nature without littering.

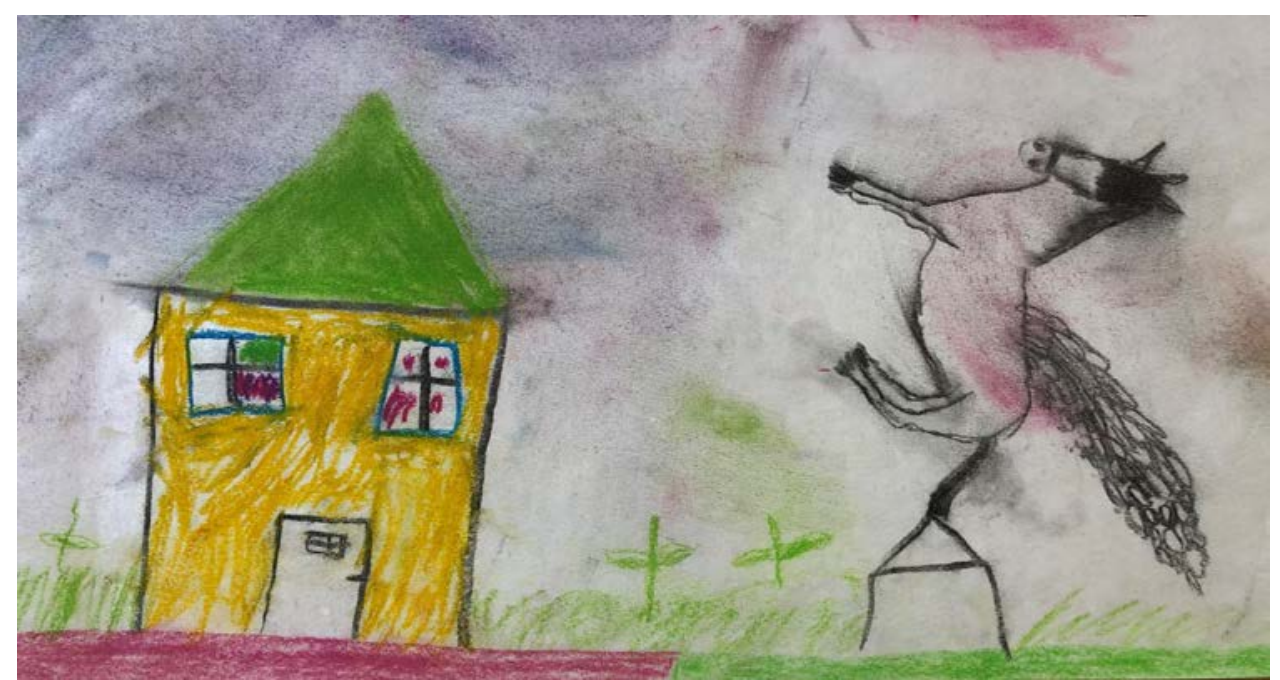

Figure 5. Two students drew a house and a horse/unicorn in a landscape without pollution. Photo: Mette Gårdvik

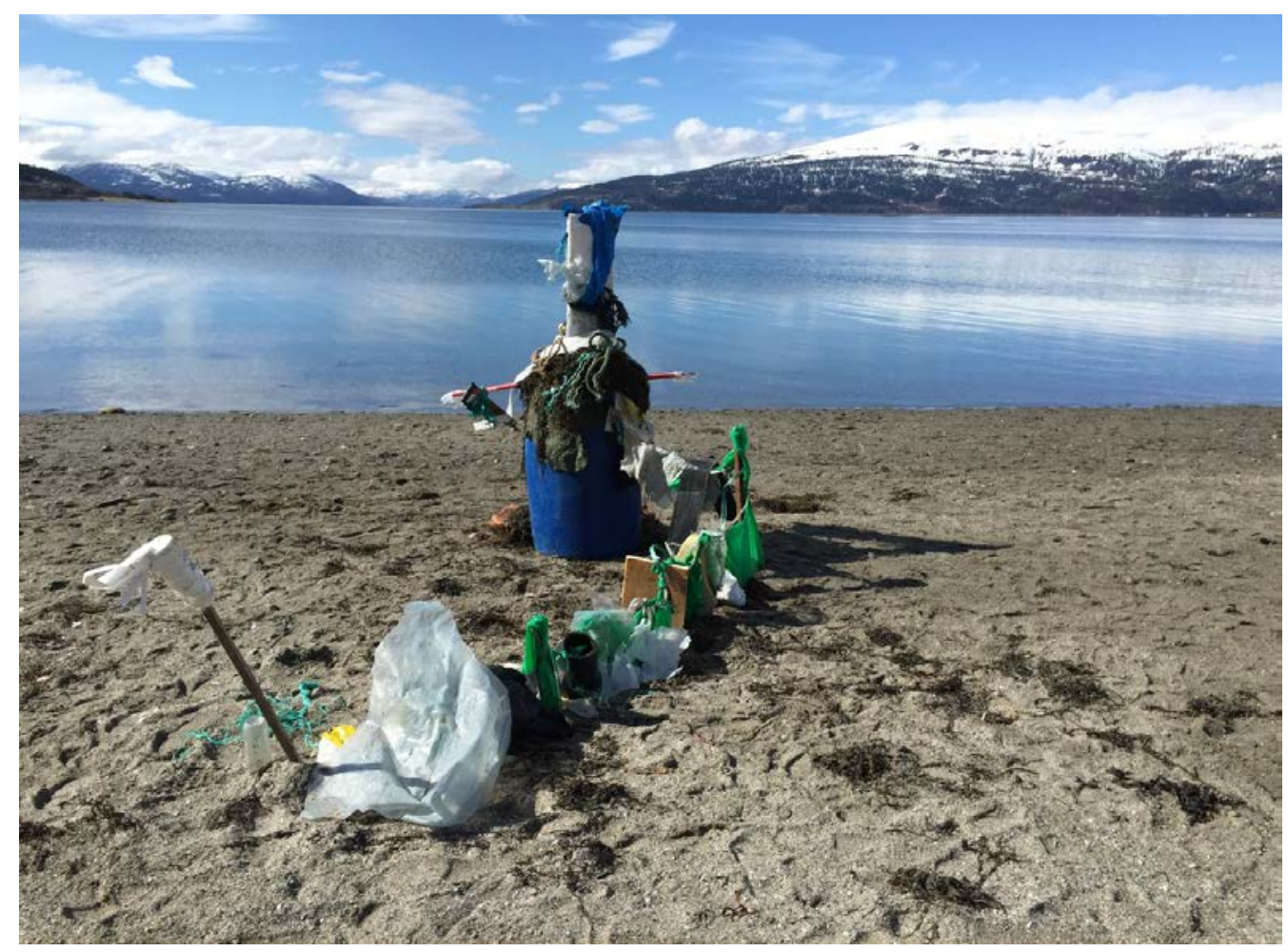

Figure 6. Photo: School A 
Only one sculpture had the coastal landscape as a conscious part of the expression and forms a whole with the surroundings. Although the sculpture in Figure 6 is built of marine plastic waste and thus shows litter, we have chosen to place it in this category. The aesthetically pleasing and clean sculpture in fine colours becomes part of, and creates an aesthetic whole with, the coastal landscape.

\section{Category 2: Experiences with marine litter}

We have selected drawings where the expressions tell us that the students have experience that rubbish is found in large quantities in the coastal zone and that this characterises the landscape (Figures 7, 8). Some students have drawn "typical" landscape pictures with sky, sea and mountains with none or few animals/people in the picture and no action. A student talks about his experiences with plastic in the sea with his grandfather:

My family was going to drive out with a big boat, and my grandfather is very focused on litter. And then while we were driving he saw a plastic bag out in the water and then he grabbed the handle next to the boat and leaned down to get hold of [the bag].
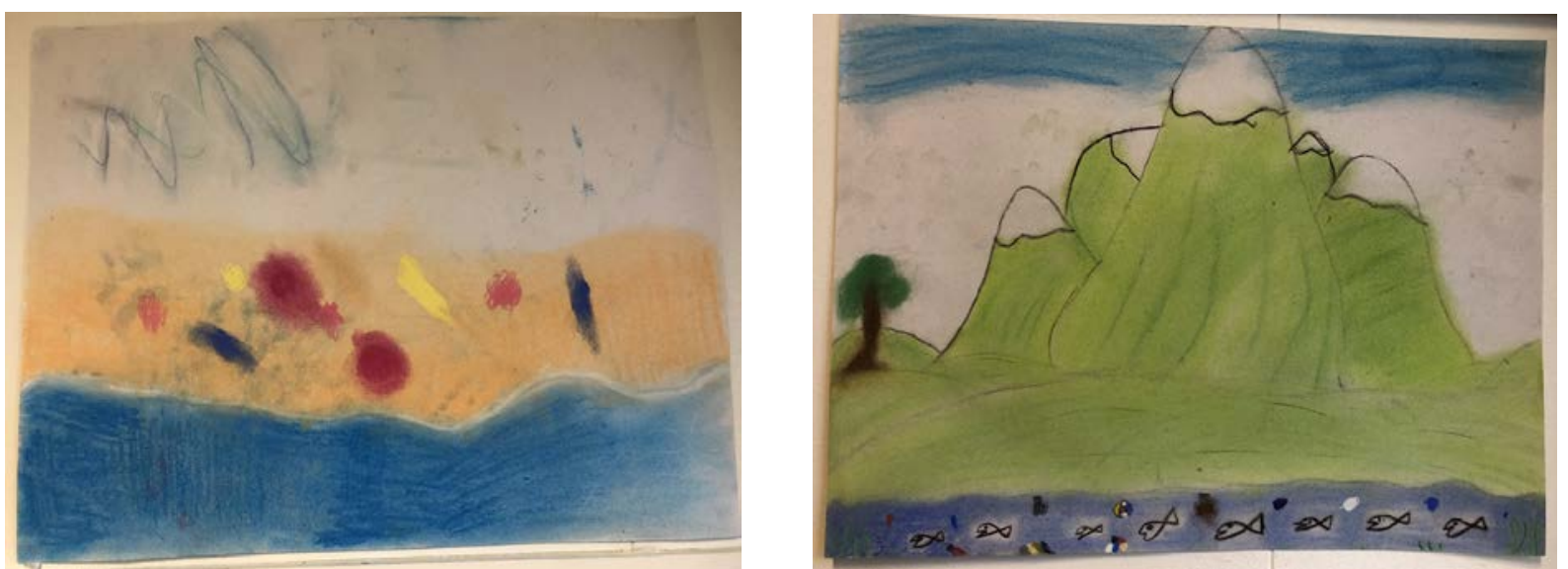

Figures 7 and 8. Students’ expressions of marine litter. Photos: Mette Gårdvik
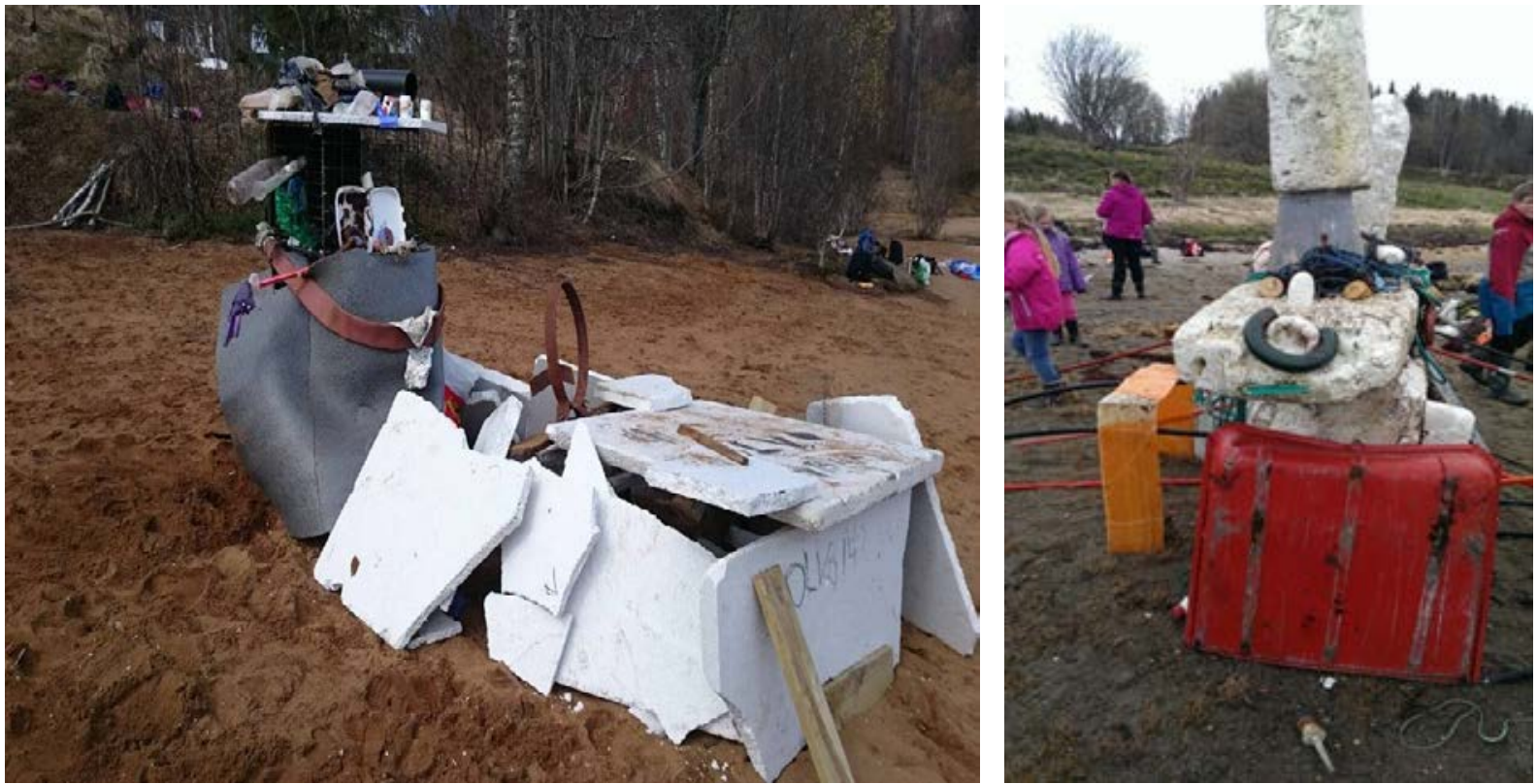

Figure 9. Photo: School B

Figure 10. Photo: School C 
The sculptures in Figures 9 and 10, which are part of this category, will convey to society what types and how much marine litter was found. While the students work, they talk a lot about their own experiences of marine litter. One student says about sculpture building with marine litter:

[I] have realised how much [litter] there actually was, and that it [beach cleaning] is important because of society, the environment and the future. Now I throw away plastic I see on the ground and things lying outside.

\section{Category 3: Empathy with animals}

This category makes up a large proportion of the drawings and three of the sculptures. The expressions show clear compassion for animals that suffer due to marine litter and also arouses strong emotions in us (Figures 11, 12, 13). We recognise images from media reports, e.g., whales with litter in their stomachs, animals caught in abandoned nets or plastic around their bodies. The students' sympathy was also expressed in conversations that took place while they were drawing: "It's a bit sad that animals, that they eat [plastic]", "It is scary to think that it is an animal [...] that eats", "It was a bit disgusting" and "It's awful!".
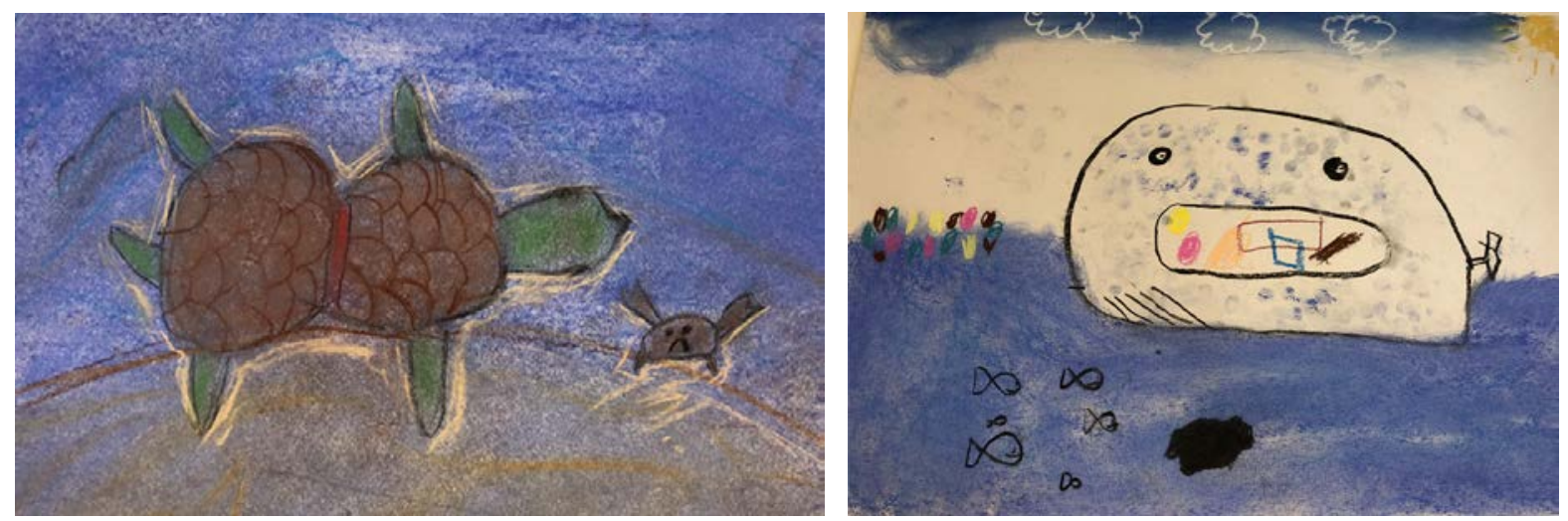

Figures 11 and 12. Photos: Mette Gårdvik

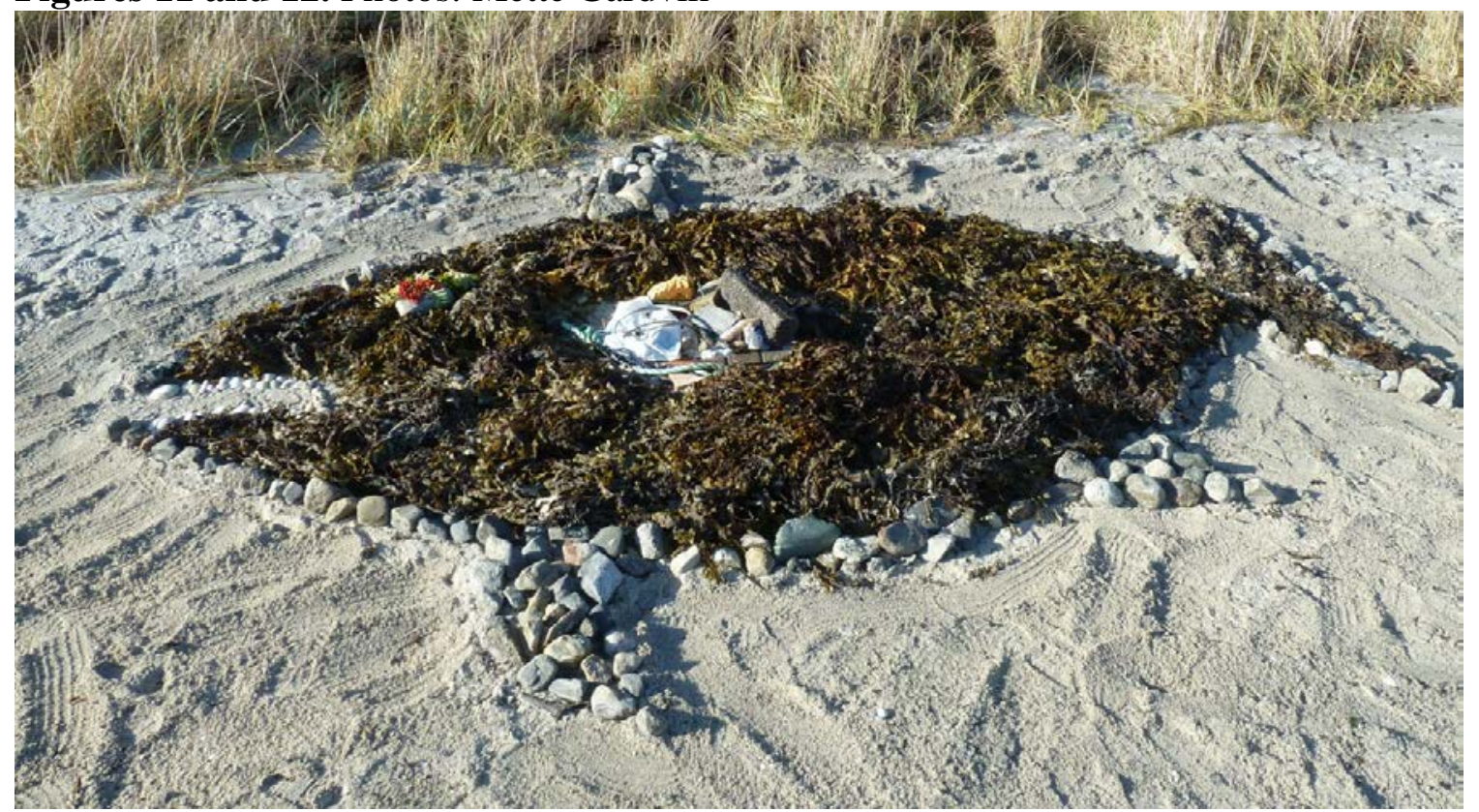

Figure 13. Photo: Mette Gårdvik 
There is great commitment and outlet for emotions in the drawing session about animals that suffer due to marine litter:

I had a bad feeling yes, because I saw how lethargic and [...] under-dedicated the human species is. We have existed for over 10,000 years, in the course of a hundred years we have exterminated $50 \%$ of the animals on earth.

\section{Category 4: System understanding}

Although several of the drawings also deal with empathy with animals, it was clear to us that the students saw connections and understood systems within the theme of marine litter (Figures 14, 15, 16). A student said while drawing:

They eat plastic because they do not know what it is, they think it is food. And then they end up, or the plastic makes less and less space, then they die of hunger because they cannot eat anything.

In the drawings, the students have a greater opportunity to tell the course of action beyond one concrete expression that a sculpture will give. The drawings describe human activity with boat freight and the fishing industry as causes of animals being injured and dying, or showing litter from land-based activities and microplastics. They illustrate a series of actions and tell us about how students have understood systems and ripple effects.
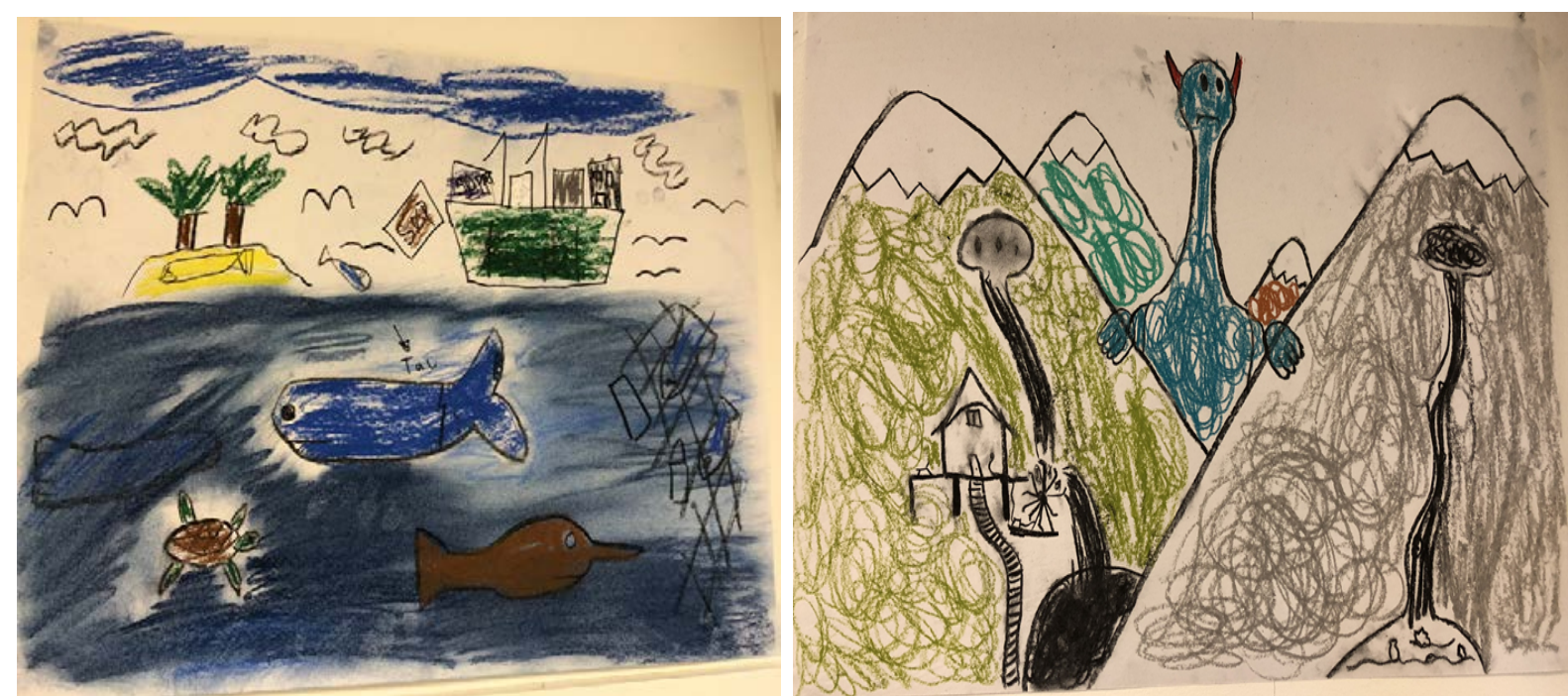

Figure 14. The drawing shows waste from fishing and some consequences for the marine environment.

Figure 15. The drawing shows that a lot of marine litter comes from land-based activities. 


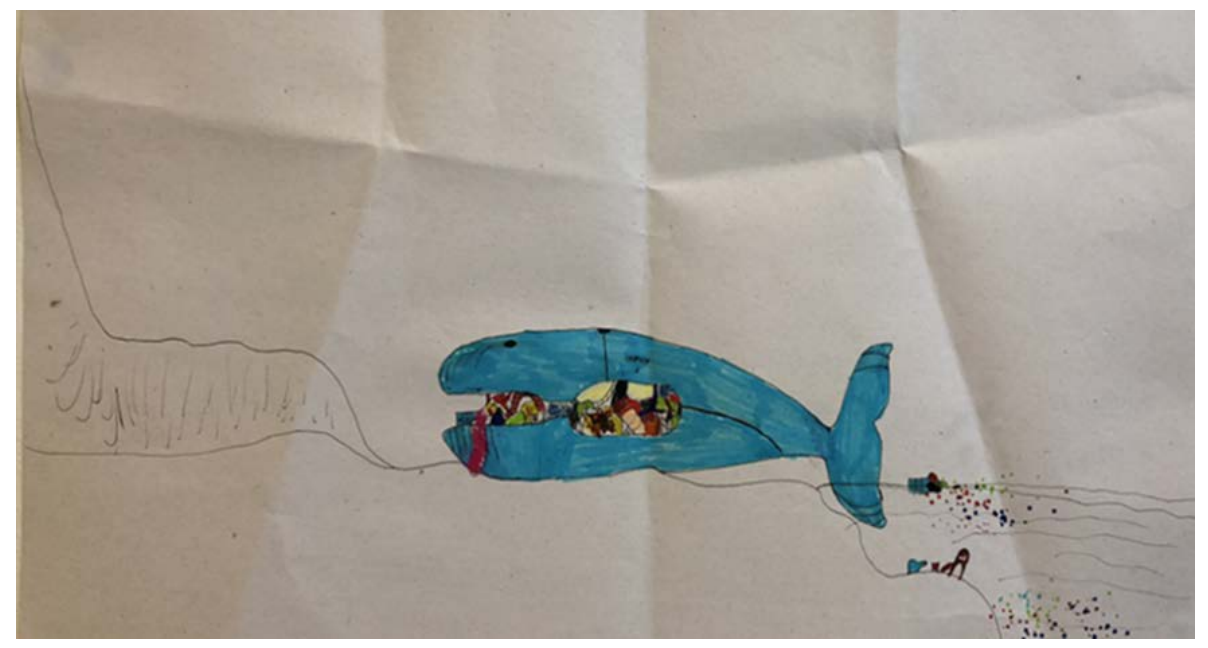

Figure 16. The drawing shows that large pieces of plastic turn into microplastic and a whale that has litter in its stomach and dies because of this.

Photos: Mette Gårdvik

\section{Category 5: Faith and hope for the future}

We collected drawings and sculptures that show that people can improve the garbage problem by standing together and acting, which we interpret as motivation, hope and faith in the future (Figures 17, 18, 19). Some drawings such as Figure 18 evoke strong emotions with us. The three large fish with crosses in their eyes represent hopelessness, where marine litter seems infinitely large in relation to what we humans can do. Nevertheless, the drawing also has a positive message with people working in teams under a colourful rainbow and a sun.
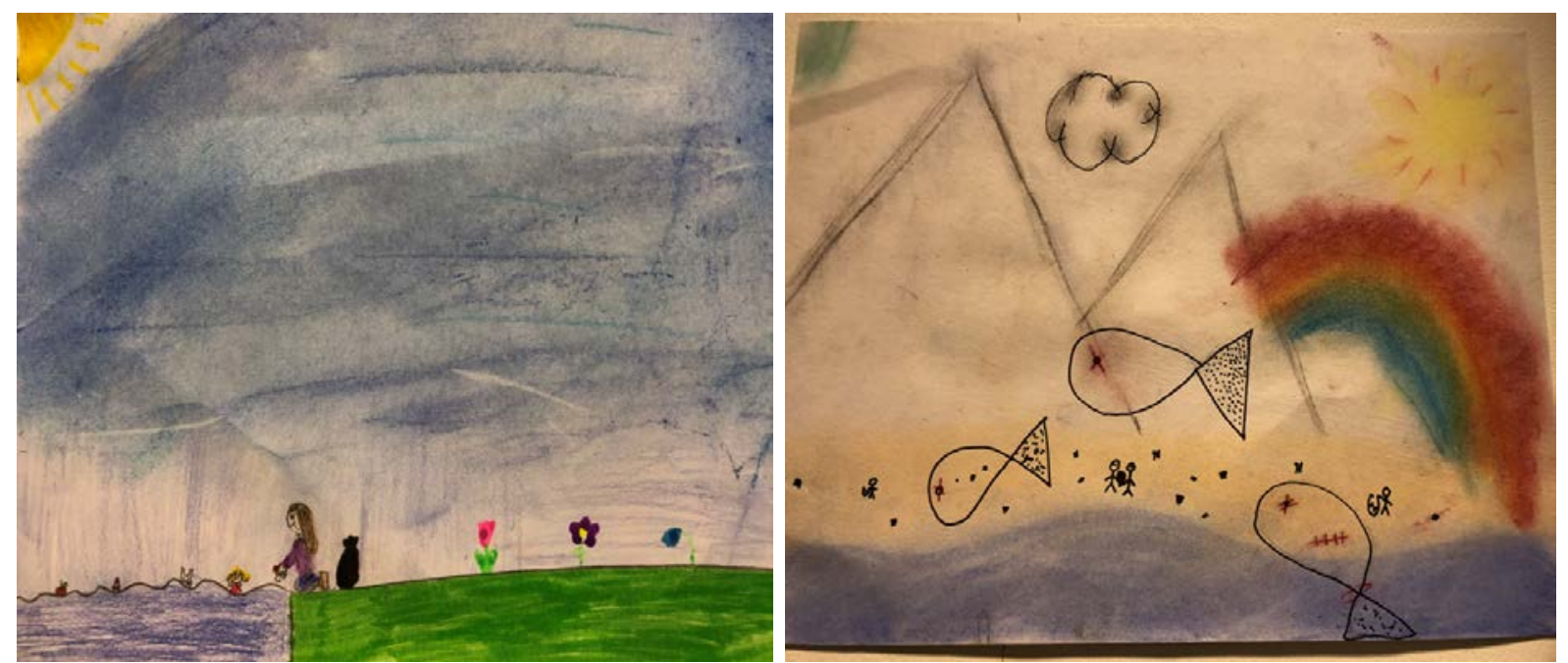

Figures 17 and 18. Photos: Mette Gårdvik

The same dualism is found in Figure 19, which is the only sculpture we interpret that expresses hope and faith for the future. It shows a turtle that has plastic in its stomach, but the students hold each other's hands in a ring around this challenge. When we stand together and work in teams, we can improve the situation. 


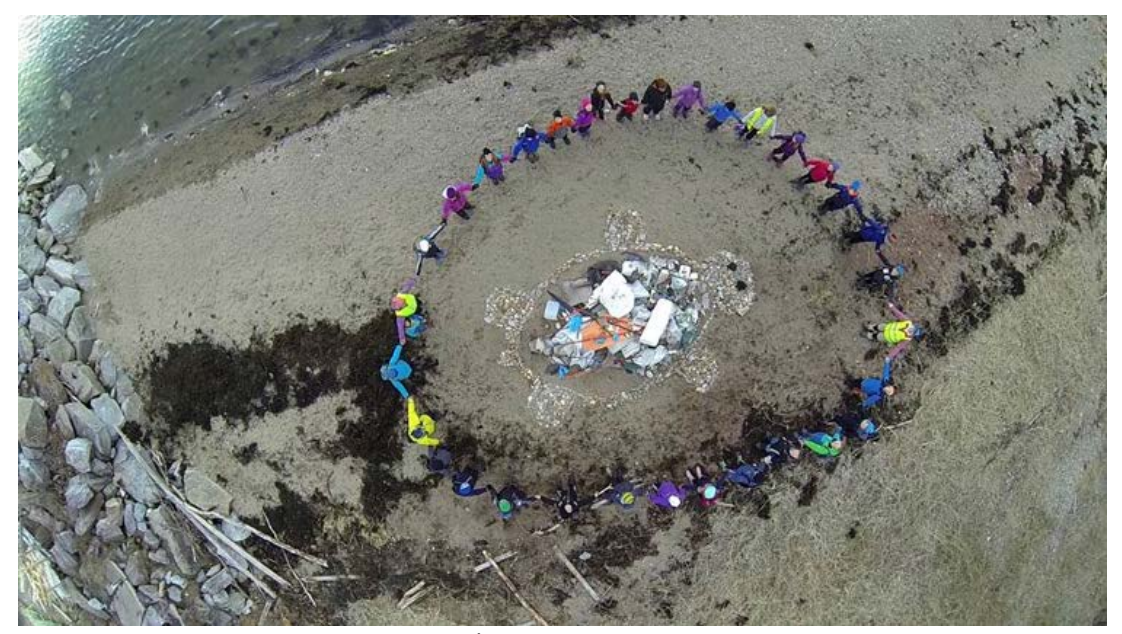

Figure 19. Photo: Robert Øyjord, Arctic Air View

\section{Category 6: Symbolism related to death}

The visual expressions use strong symbolism about death, are gloomy and show depravity (Figures 20, 21, 22). The emotions are strongly visible and appear as a wake-up call to the world about what happens if we humans do not change our behaviour. Expressions also include written appeals such as "Sharpen up!”, "Do not litter!” and "Keep the sea clean!” (Figure 21).
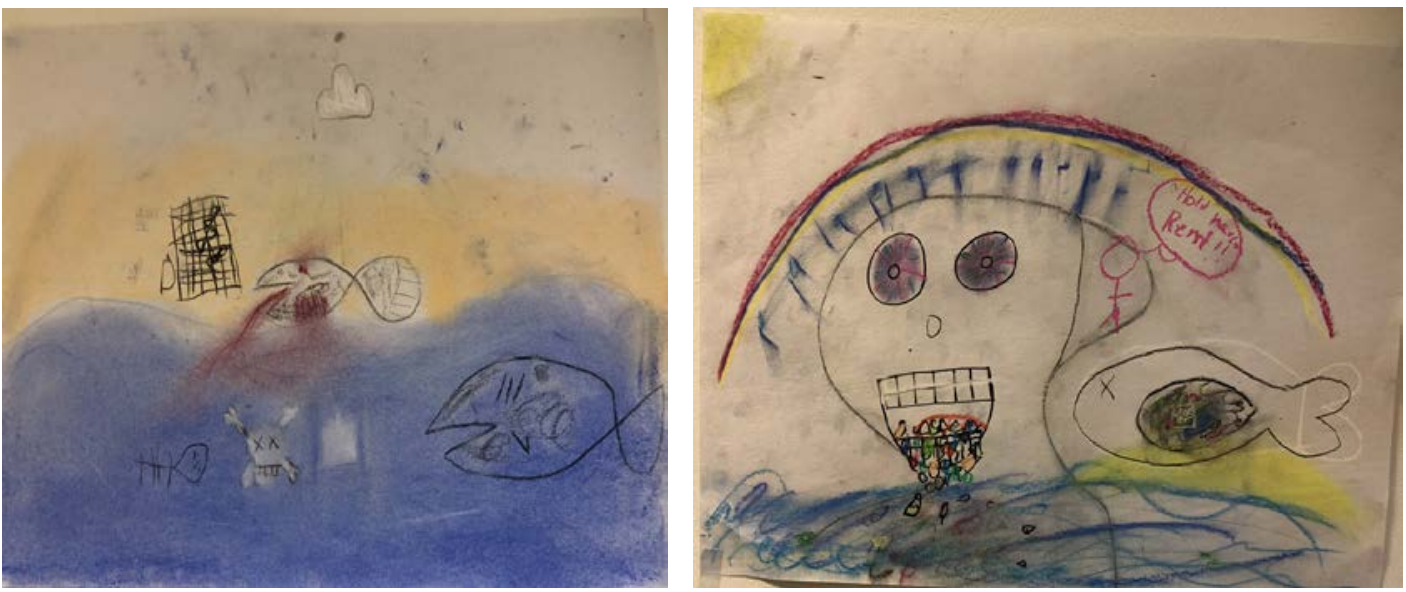

Figures 20 and 21. Photos: Mette Gårdvik

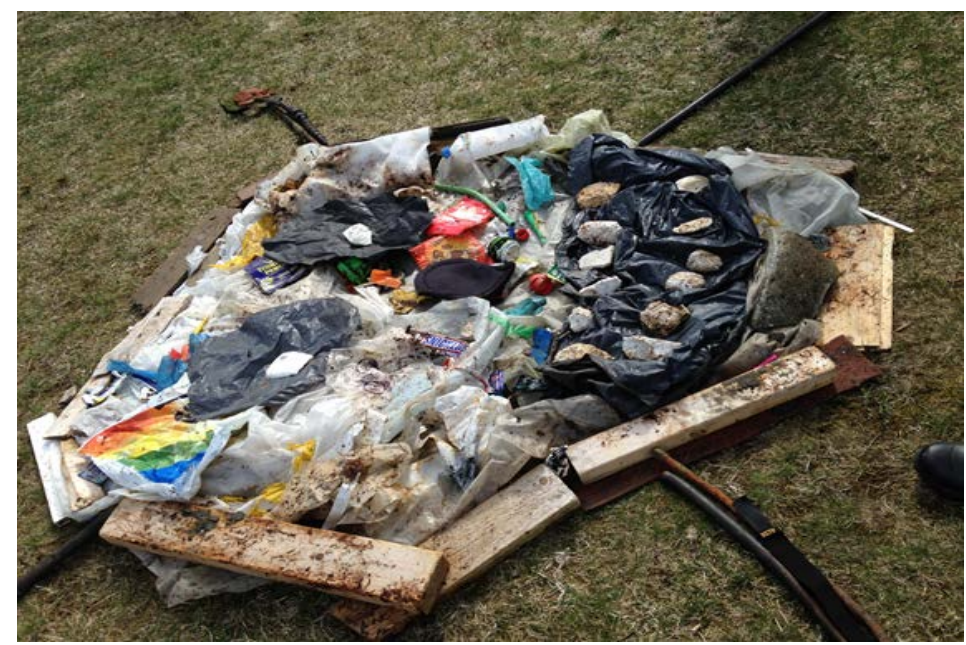

Figure 22. Photo: Wenche Sørmo 
During the sculpture construction, students had conversations between them that showed that they had ownership over their beach:

[...] this summer [...] remember several times when we have been swimming with friends and it is these friends who start throwing litter in the sea. Then we say "No, you have to jump into the sea and pick it up again because it should not be the case that there are boxes and paper floating out in the sea. It's not good.”

\section{Discussion of method}

It turned out that VABPM (Leavy, 2015, p. 232) was well suited to make visible the students' feelings, understanding and knowledge of marine litter, even if they were not professional artists. This is in line with Bradshaw (2010), Frisch (2013) and Hopperstad (2005) who show that children's drawings and sculptures can give us insight, through a dialogue with us as researchers, into the students' world of values and thoughts in a visual way where words are often not sufficient.

We are not trained psychologists and have no prerequisites for analysing the visual expressions in a psychological setting and this was not a goal of the research project. Nevertheless, we as educators can engage in dialogue and interpret drawings and sculptures to find out what they express, which is in line with Mantere (1992). Such dialogue is important to gain insight into how multifaceted the expressions are and not just death and depravity, which is immediately a very prominent expression. Behind this, one can gain insight into the students' expressions of interaction, hope, joy and knowledge. Our research perspectives are characterised by the theme; we were both researchers, teachers and project managers. We are aware that the analysis is influenced by our experiences and that others may interpret the visual expressions in different ways.

The analysis helped us to find nuances in the expressions. We discussed whether it was justifiable to use the same analysis method for the individual drawings and the common sculptural expressions. In the exhibitions, the drawings and sculptures represented an overall expression and a whole in an Eco Art perspective. We thus found it appropriate to analyse them using the same method.

\section{Discussion of results}

\section{Students as social agents}

Through published and exhibited Eco Art, students expressed what they want the world to look like (Category 1 ) and why and what this is due to (Categories 2, 4). Students also express what happens if we do not address the problem (Categories $3,4,6)$. We also find messages that show what we, through awareness and interaction, can do to improve the situation and give hope for a better future (Category 5). Through Eco Art, students gained experience in influencing their community 
and thereby gain ownership of environmental challenges. This, in a cultural sustainability perspective, strengthens their relationship with the local environment (Härkönen et al., 2018; Sazonova, 2014; Jokela \& Coutts, 2018; Mantere, 1995).

Through Eco Art as a creative learning arena, students can meet people with different interests in society. In line with Eisner (2002), the arts can help students learn that a problem can have more than one solution and that a question can have several answers. The creative way of working in the project gives students opportunities to increase their own awareness of real issues and develop skills such as social responsibility and critical thinking. The students' sculptures of marine litter appear as announcements for an environmental problem and help to put a serious societal problem on the agenda. These are important skills for participation in public debate and development (Eisner, 2002; Coutts, 2013; Thornes, 2008; Gårdvik, 2010), and to act in a sustainable way. Work with creating and exhibiting Eco Art is a constructive experience that helps to solve a problem, provides positive experiences and will promote students' action competence for SD, which is mentioned by Sinnes (2015, 2020) as the main goal of ESD.

Our research shows that Eco Art is an important contribution to students being able to have a strong influence on and insight into society through artistic expression. This element is absent from the Norwegian AC curriculum dealing with ESD. Therefore, it will be challenging for a teacher who wants to work with Eco Art in an ESD project, to find an anchor for this in LK20.

In Category 4, students show understanding of systems in society that lead to marine litter. Through practical creative work and aesthetic experience, students' eco-literacy can be developed, which according to Lutnæs (2015) and Lutnæs and Fallingen (2017), includes critical reflection, awareness-raising and change competence. The physical is a prerequisite for the students' development of critical thinking, i.e., a cognitive creativity. In our project, physical and sensory first-hand experiences with garbage collection are also crucial for students' understanding of the problem, motivation to learn, and desire to act. The significance of this is expressed in both visual and verbal expressions (Categories 2, 5), where students show that they need first-hand experience with the problem to act together, which promotes faith and hope for the future (Figures 18, 19 ). In this way, AC contributes centrally to ESD didactics and this challenges the more cognitive definition of the concept of creativity in LK20 (Udir, 2020). This is in line with Dahl and Østern (2019), Sinnes and Straume (2017) and Damasio (2000) in relation to their views on in-depth learning which includes the affective and bodily, sensory, relational and creative part of learning. Aesthetic subjects take care of children's holistic learning to a greater extent than other school subjects do, according to both Fredriksen (2013), Eisner (2002) and Østergaard (2013). In accordance with Johansson (2019), our results indicate that the opportunity space that lies in the AC subject is not reflected in the competence goals for SD in LK20. It will be challenging for teachers and educators to see that the AC subject should 
be included in all parts of ESD. This space of opportunity must be further explored from an AC professional point of view.

\section{Students' expression of feelings about marine litter}

We were not prepared for the large scale of strong feelings students expressed about the topic. The drawing process and sculpture construction initiated multifaceted dialogues that revolved around their experiences and their and others' attitudes, which in turn contributed to raising awareness of the problem. Many students had a great need to talk while drawing and sculpting, and it could be a way for them to process and put into words their feelings about marine litter. Working with visual expressions on difficult topics can help students express and vent their emotions, and provide a deeper insight into their emotional world (Bradshaw, 2010). Even though we observed a certain degree of imitation among students, the drawings still had characteristics of the individual student's world of life. This is in line with Hopperstad (2005), Van Manen (1990) and Frisch (2013) who claim that visual expressions say something about experiences students have as active, living and sensing individuals, which represent the students' world and what they want to share.

It is important that the teacher opens up for visual expressions and oral statements to be treated respectfully in the classroom, and at the same time tries to convey hope for the future. In this way, the teacher can help students express themselves and cope with the difficult emotions (Lowenfeld \& Brittain, 1976; Mantere, 1992). In an ESD perspective, this is a central task for the teacher and crucial for the students' reflections on the topic and thus also their learning (Folkman, 2009; Ojala, 2013). Ojala (2013) criticises that ESD pays little attention to students' emotional world, and here we see that the AC subject has a key function beyond the competence goals described in LK20 (Udir, 2020).

Some students showed that the world is nice and without a trace of litter (Category 1). These drawings and sculptures appear as a wishful thinking situation, while the main message in the majority of the drawings is characterised by emotions such as empathy, suffering, despair and fear (Categories 3, 6). Students feel this and whoever looks at the expressions will also be able to understand it. Although it can be difficult for the students and us as viewers to take these feelings seriously, Ojala (2007) and Persson et al. (2011) showed that such emotions are important in order to motivate students to action and trigger hope for the future. Within place-based learning, closeness to, and experiences in nature are important for the students to want to take care of the environment (Sørmo et al., 2019). In ESD, issues based on the students' immediate environment are essential to make the teaching engaging, relevant and rooted in their world, and provide the experiences that include affective aspects (Sinnes, 2015; Sørmo et al., 2013; Gårdvik et al., 2015). Development of identity and involvement in issues related to one's own local environment is also important in relation to the cultural sustainability perspective (Figure 1) (Sazonova, 2014; Härkönen et al., 2018). In the 
coastal communities, the fishing and aquaculture industries characterise the culture. Students worked with marine litter, mostly plastic, from these industries and were motivated to explore these sources in the project's follow-up. Through the work with garbage collection and sculpture building, the students gained ownership of the place and developed a stronger relationship and a greater responsibility to take care of it. This is shown especially in Category 5, faith and hope for the future, which shows that people take responsibility and clean up the beaches. In this way, each individual as part of a community can contribute directly to a more sustainable future.

\section{Conclusion}

This article has problematised several dimensions of AC's contribution to ESD beyond what is described in LK20. Our research results indicate that AC plays an important role in relation to the students' ability to express and process feelings about challenging topics. Strong emotions are important in order to motivate action and trigger hope for the future. AC is a key subject in ESD by giving students opportunities to express their emotions visually, and in this way contribute strong messages into societal debates. Artistic expression appears as an active contribution to society and also gives students insight into the local community's various conflicts of interest. In addition, students work creatively and relationally in the AC subject. The bodily/sensory way of working also promotes cognitive skills that are important in ESD, such as critical thinking and cognitive creativity. These are important skills in relation to the development of conscious attitudes and action for SD.

With this article, we want to open up a discussion about AC's role in ESD and how it can be raised in relation to interdisciplinary ESD projects in schools beyond the technology focus on product development, materials knowledge, re- and upcycling.

\section{Acknowledgement}

The research project is funded by the University of the Arctic and Nordland County Municipality.

Translation by Gary Hoffman, associate professor, Faculty of Education and Arts, Nord University. 


\section{About the authors}

Karin Stoll is an associate professor of science didactics at Nord University. She is a trained zoologist from the University of Erlangen-Nürnberg, Germany. Her main research concerns education for sustainable development, creative working methods and place-based learning in natural science in teacher education.

Institutional affiliation: Faculty of Education and Arts, Nord University, 8700 Nesna, Norway.

E-mail: karin.stoll@nord.no

Mette Gårdvik is an associate professor of arts and crafts at Nord University. Her background is in arts and design education and her main research concerns education for sustainable development in teacher education and conservation of handicraft skills in addition to community art.

Institutional affiliation: Faculty of Education and Arts, Nord University, 8700 Nesna, Norway.

E-mail: mette.gardvik@nord.no

Wenche Sørmo is an associate professor of natural science at Nord University. She has a background in comparative physiology, and is Dr. Scient. from the University of Tromsø. Her main research concerns creative and interdisciplinary working methods, education for sustainable development and place-based learning in teacher education.

Institutional affiliation: Faculty of Education and Arts, Nord University, 8700 Nesna, Norway.

E-mail: wenche.sormo@nord.no 


\section{References}

Ahlskog-Björkman, E., Porko-Hudd, M., Koch, M., Westerlund, S., \& Carlsen, K. (2020). Nordiska slöjdpedagogers syn på hållbar utveckling som innehåll i slöjdundervisningen [Nordic sloyd pedagogues' views on sustainable development as content in sloyd teaching]. Techne Series, 27(2), 64-80. https://hdl.handle.net/11250/2753809

Austin, J. (2008). Training Community Artists in Scotland. In G. Coutts \& T. Jokela (Eds.), Art, Community and Environment. Educational Perspectives (pp. 175-192). Intellect Books.

Bradshaw, G. A. (2010). You see me, but do you hear me? The science and sensibility of trans-species dialogue. Feminism \& Psychology, 20(3), 407-419. https://doi.org/10.1177/0959353510368285

Breiting, S. (2011). Et paradigmeskift for miljøundervisning - på vej mod Uddannelse for Bæredygtig Udvikling [A paradigm shift in environmental education - towards education for sustainable development]. In K. Kragh Blume Dahl, J. Læssøe, \& V. Simovska (Eds.), Essays om dannelse, didaktik og handlekompetanse - inspirert af Karsten Schnack (pp. 93-104). Danmarks Pædagogiske Universitetsskole, Århus Universitet.

Breiting, S., \& Mogensen, F. (1999). Action competence and environmental education. Cambridge Journal of Education, 29(3), 349-353. https://doi.org/10.1080/0305764990290305

Brenson, M. (2001). Visionaries and Outcasts: The NEA, Congress, and the Place of the Visual Artist in America. New York Press.

Coutts, G. (2013). Applied Visual Arts: Learning for the real world? In T. Jokela, G. Coutts, M. Huhmarniemi, \& E. Härkönen (Eds.), Cool. Applied Visual Arts in the North (pp. 2231). Erweko Oy.

Creswell, J. W. (2013). Qualitative Inquiry \& Research Design: Choosing Among Five Approaches ( $3^{\text {rd }}$ edition). Sage Publications.

Dahl, T., \& Østern, T. P. (2019). Dybde//læring med overflate og dybde [Depth//learning with surface and depth]. In T. P. Østern, T. Dahl, A. Strømme, J. A. Petersen, A.-L. Østern, \& S. Selander (Eds.), Dybdelcring - en flerfaglig, relasjonell og skapende tilncerming (pp. 39-53). Universitetsforlaget.

Damasio, A. R. (2000). The feelings of what happens: Body, emotion and the making of consciousness. Vintage.

Dewey, J. (2005/1934). Art as experience. Penguin Putnam Inc.

Eisner, E. (2002). The Arts and Creation of Mind. Yale University Press.

Folkman, S. (2009). Commentary on the special section "Theory-based approaches to stress and coping”: Questions, answers, issues, and next steps in stress and coping research. European Psychologist, 14(1), 72-77. https://doi.org/10.1027/1016-9040.14.1.72

Fredriksen, B. C. (2013). Begripe med kroppen. Barns erfaringer som grunnlag for all læring [Understanding with the body. Children's experiences as foundation for all learning]. Universitetsforlaget.

Frisch, N. S. (2013). Tegningen lever! Nye dialogiske perspektiver på tegneundervisning i grunnskolen [Drawing is alive! New dialogical perspectives on drawing teaching in primary and lower secondary school]. Akademika.

Gårdvik, M. (2010). Arbeid med kniv i rått tre - bruk av kniv som redskap for tradering av håndverks- og kulturarv [Working with knife in raw wood - use of knife as a tool for trading handicraft and cultural heritage]. In T. M. Guldal (Ed.), FoU i Praksis 2009. Rapport fra konferanse om praksisrettet FoU i lcererutdanning (pp. 67-79). Tapir Akademisk Forlag. 
Gårdvik, M. (2011). Community art og skapende prosesser i naturmaterialer [Community art and creative processes in natural materials]. In T. Løkensgard Hoel, T. M. Guldal, C. F. Dons, S. Sagberg, T. Solhaug \& K. Wæge (Eds.), FoU i praksis 2010. Rapport fra konferanse om praksisrettet FoU i læererutdanning (pp. 157-165). Tapir Akademisk Forlag.

Gårdvik, M., Stoll, K., \& Sørmo, W. (2015). Avskyelige snømenn og Land Art i fjæra [Abominable snowmen and Land Art in the tidal zone]. In T. Ansnes (Ed.), Rapport fra konferansen Forskning i friluft 2015 (pp. 181-185). Norsk Friluftsliv. http://www.norskfriluftsliv.no/wp-content/uploads/2015/12/Forskning-i-friluft-2015Rapport-e-bok.pdf

Gårdvik, M., Stoll, K., \& Sørmo, W. (n.d.). Sjøuhyret i fjæra - kreativt arbeid med marin forsøpling [Sea monster in the tidal zone - creative work with marine litter]. Undervisningsressurs. Nasjonalt senter for kunst og kultur i opplæringen. https://kunstkultursenteret.no/ressursbase/sjouhyret-i-fjaera-kreativt-arbeid-i barnehagenmed-marin-forsopling/

Hiltunen, M. (2008). Community-based art education in the North: A space for agency? In G. Coutts \& T. Jokela (Eds.), Relate North. Art, Community and environment: Educational perspectives (pp. 91-112). Intellect Books.

Hopperstad, M. H. (2005). Alt begynner med en strek. Når barn skaper mening med tegning [It all starts with a line. When children create meaning with drawing]. Cappelen Akademisk forlag.

Härkönen, E., Huhmarniemi, M., \& Jokela, T. (2018). Crafting Sustainability: Handcraft in Contemporary Art and Cultural Sustainability in the Finnish Lapland. Sustainability, 10(6), 1907. https://doi.org/10.3390/su10061907

Illeris, H. (2017). Subjectivation, togetherness, environment. Potentials of participatory art for Art Education for Sustainable Development (AESD). Nordic Journal of Art and Research, 6(1). https://doi.org/10.7577/information.v6i1.2166

Johansson, M. (2019). Materiella och immateriella resurser - hållbar utveckling i och genom slöjd [Material and immaterial resources - sustainable development in and through sloyd]. Nordic Studies in Education, 39(3), 214-227. https://doi.org/10.18261/issn.1891-59492019-03-04

Jokela, T., \& Coutts, G. (2018). Preface. In T. Jokela \& G. Coutts (Eds.), Relate North: Practising Place, Heritage, Art \& Design for Creative Communities (pp. 6-13). Lapland University Press. http://urn.fi/URN:ISBN:978-952-310-950-6

Jónsdóttir, Á. B. (2017). Artistic Actions for Sustainability: Potential of Art in Education for Sustainability. University of Lapland.

KD (2016). Fag - Fordypning - Forståelse. En fornyelse av Kunnskapsløftet [Subjects Immersion - Understanding. A renewal of the Norwegian curriculum]. White paper: Meld. St. 28 (2015-2016). Ministry of Education and Research. https://www.regjeringen.no/contentassets/e8e1f41732ca4a64b003fca213ae663b/no/pdfs/s $\underline{\text { tm201520160028000dddpdfs.pdf }}$

KD (2017). Overordnet del - verdier og prinsipper for grunnopplceringen [Overall part values and principles for education]. Ministry of Education and Research. https://www.regjeringen.no/contentassets/37f2f7e1850046a0a3f676fd45851384/overordn et-del---verdier-og-prinsipper-for-grunnopplaringen.pdf

Kielland, I. M. (2021). Fortellinger om håp og håpløshet - Bærekraftsundervisning i antropocen [Stories about hope and hopelessness - Teaching sustainability in the Anthropocene]. Acta Didactica Norden, 15(2), Art. 3. https://doi.org/10.5617/adno.8150

Kopnina, H. (2012). Education for sustainable development (ESD): the turn away from 'environment' in environmental education? Environmental Education Research, 18(5), 699-717. https://doi.org/10.1080/13504622.2012.658028 
Kopnina, H. (2014). Future scenarios and environmental education. Journal of Environmental Education, 45(4), 217-231. https://doi.org/10.1080/00958964.2014.941783

Koritzinsky, T. (2021). Tverrfaglig dybdelcering. Om og for demokrati og medborgerskap bcrekraftig utvikling - folkehelse og livsmestring [Interdisciplinary in-depth learning. About and for democracy and citizenship - sustainable development - public health and life skills]. Universitetsforlaget.

Korsager, M., \& Scheie, E. (2014). Nøkkelfaktorer for utdanning for bærekraftig utvikling et eksempel fra en norsk ungdomsskole [Key factors for education for sustainable development - an example from a Norwegian upper secondary school]. Naturfag, (2), 2631. https://www.natursekken.no/c1187995/artikkel/vis.html?tid=2102116

Korsager, M., \& Scheie, E. (2019). Students and education for sustainable development what matters? A case study on students' sustainability consciousness derived from participating in an ESD project. Acta Didactica Norge, 13(2), Art. 6. https://doi.org/10.5617/adno.6451

Kvamme, O. A. \& Sæther, E. (Eds.) (2019). Bærekraftdidaktikk [The didactics of education for sustainable development]. Fagbokforlaget.

Lave, J., \& Wenger, E. (1991). Situated Learning: Legitimate Peripheral Participation. Cambridge University Press.

Leavy, P. (2015). Method Meets Art: Arts-Based Research Practice. Guildford Press.

Lowenfeld, V., \& Brittain, V. L. (1976). Kreativitet og vakst: En redegørelse for den tegnepsykologiske udvikling hos børn og unge og nogle pædagogiske konsekvenser [Creativity and growth: An account of the psychological drawing development in children and in young people and some pedagogical consequences]. Gjellerup.

Lutnæs, E. (2015). Kritisk refleksjon og systemorientert design - Bevisstgjøring og endringskompetanse gjennom Utdanning for bærekraftig forbruk [Critical reflection and systemoriented design - Awareness raising and change competence through education for sustainable consumption]. Form Akademisk, 8(3), Art. 3. https://doi.org/10.7577/formakademisk.1433

Lutnæs, E., \& Fallingen, N. (2017). Bærekraftig utvikling gjennom skapende praksis [Sustainable development through creative practice]. Form Akademisk, 10(3), Art. 4. https://doi.org/10.7577/formakademisk.1825

Manders, E., \& Chilton, G. (2013). Translating the essence of the dance: Rendering meaning in artistic inquiry of the creative arts therapies. International Review of Qualitative Research, 14(16), 1-17.

Mantere, M.-H. (1992). Ecology, Environmental Education and Art Teaching. In L. Piironen (Ed.), Power of Images (pp. 17-27). INSEA Research Congress.

Mantere, M.-H. (1995). Foreword. In M.-H. Mantere (Ed.), Image of the Earth: Writings on art-based environmental education (pp. 1-2). Helsinki University of Art and Design.

Massumi, B. (1995). The Autonomy of Affect. Cultural Critique, 31, 83-109. https://doi.org/10.2307/1354446

Milbrandt, M. K. (2002). Addressing contemporary social issues in art education: a survey of public school art educators in Georgia. Studies in Art Education, 43(2), 141-157. https://doi.org/10.2307/1321001

Miljødirektoratet (n.d.). Miljøstatus. Forsøpling av havet [Littering of the sea]. Norwegian Environmental Agency. https://miljostatus.miljodirektoratet.no/tema/avfall/forsopling-avhavet/

Mogensen, F., \& Schnack, K. (2010). The action competence approach and the 'new' discourses of education for sustainable development, competence and quality criteria. Environmental education research, 16(1), 59-74. https://doi.org/10.1080/13504620903504032 
Nielsen, L. M. (2009). Fagdidaktikk for kunst og håndverk i går - i dag - i morgen [Subject didactics in arts and crafts yesterday - today - tomorrow]. Universitetsforlaget.

NOU (2015:8). Fremtidens skole. Fornyelse av fag og kompetanser [The school of the future. Renewal of subjects and competences]. Report from a commission appointed by the Ministry of Education and Research. https://www.regjeringen.no/no/dokumenter/nou2015-8/id2417001/

Näumann, R., Riis, K., \& Illeris, H. (2020). Bærekraftdidaktikk i kunst og håndverk. Gjenbruke - Oppvinne - Skape [The didactics of education for sustainable development in arts and crafts. Reuse - Upcycle - Create]. Cappelen Damm Akademisk.

Ojala, M. (2007). Confronting macrosocial worries: Worry about environmental problems and proactive coping among a group of young volunteers. Futures, 39(6), 729-745. https://doi.org/10.1016/j.futures.2006.11.007

Ojala, M. (2013). Emotional Awareness: On the Importance of Including Emotional Aspects in Education for Sustainable Development (ESD). Journal of Education for Sustainable Development, 7(2), 167-182. https://doi.org/10.1177\%2F0973408214526488

Ojala, M. (2017). Hope and anticipation in education for a sustainable future. Futures, 94, 7684. https://doi.org/10.1016/j.futures.2016.10.004

Olsson, D., Gericke, N., \& Chang Rundgren, S.-N. (2016). The effect of implementation of education for sustainable development in Swedish compulsory schools - assessing pupils' sustainability consciousness. Environmental Education Research, 22(2), 176-202. https://doi.org/10.1080/13504622.2015.1005057

Öhman, J. (2006). Pluralism and criticism in environmental education and education for sustainable development: a practical understanding. Environmental Education Research, 12(2), 149-163. https://doi.org/10.1080/13504620600688856

Permar, R. (2019). Connect and Collaborate. In M. Hiltunen, I. Zemtsova, N. Bazhenova, A. Lyantsevich, \& T. Tupenko (Eds.), Relate North 2019: Tradition \& Innovation in Art \& Design Education, (pp. 72-73). University of Lapland.

Persson, L., Lundegård, I., \& Wickman, P.-O. (2011). Worry becomes hope in education for sustainable development - an action research study at a secondary school. Utbildning och demokrati, 20(1), 123-144. https://doi.org/10.48059/uod.v20i1.946

Samuelsen, A. N. (2013). Formidling av kunst til barn og unge [Dissemination of art to children and young people]. Universitetsforlaget.

Sazonova, L. (2014). Cultural Aspects of sustainable Development. Glimpses of the Ladies' Market. Friedrich Ebert Stiftung.

Scheie, E. I., \& Korsager, M. (2017). Nordisk arbeidsmodell for Undervisning for bcerekraftig utvikling [Nordic working model for education for sustainable development]. Naturfagsenteret, Rapport nr. 1/2017.

Scheie, E. I., \& Stromholt, S. (2019). “The Sustainable Backpack”: Exploring possibilities in education for sustainable development through a nationwide professional development program. Acta Didactica Norge, 13(2), Art. 5. https://doi.org/10.5617/adno.6473

Sinnes, A. T. (2015). Utdanning for bærekraftig utvikling; hva, hvorfor og hvordan? [Education for sustainable development: what, why and how?]. Universitetsforlaget.

Sinnes, A. T. (2020). Action takk! Hva kan skolen læere av unge menneskers handlinger for bcrekraftig utvikling? [Action thanks! What can the school learn from young people`s actions for sustainable development?]. Oslo: Gyldendal.

Sinnes, A. T., \& Jegstad, K. M. (2011). Utdanning for Bærekraftig Utvikling: To unge realfagslæreres møte med skolehverdagen [Education for sustainable development: Two young science teachers` meeting with school life]. Norsk pedagogisk tidsskrift, 95(4), 248-259. https://doi.org/10.18261/ISSN1504-2987-2011-04-02 
Sinnes, A. T., \& Straume, I. S. (2017). Bærekraftig utvikling, tverrfaglighet og dybdelæring: fra big ideas til store spørsmål [Sustainable development, interdisciplinarity and in-depth learning: From big ideas to big questions]. Acta Didactica Norge, 11(3), Art. 7. https://doi.org/10.5617/adno.4698

Soini, K., \& Birkeland, I. (2014). Exploring the scientific discourse on cultural sustainability. Geoforum, 51, 213-223. https://doi.org/10.1016/j.geoforum.2013.12.001

Soini, K., \& Dessein, J. (2016). Culture-Sustainability Relation: Towards a Conceptual Framework. Sustainability, 8(2), 167. https://doi.org/10.3390/su8020167

Solheim, Å. R. (2009). Hva kan læres gjennom kunst og håndverk? Hvilke generelle kompetanser kan elever med utviklingshemning utvikle gjennom kunst- og håndverksfaget? [What could be learned through arts and crafts? What general competences can pupils with developmental disabilities develop through the subject of arts and crafts?]. Master thesis, University of Oslo.

https://www.duo.uio.no/bitstream/handle/10852/32138/masteroppgavexxsolheimx1.pdf?s equence $=1$

Stevenson, R. B., Wals, A. E. J., Dillon, J., \& Brody, M. (2013). Introduction: an orientation to environmental education and the handbook. In R. B. Stevenson, B. Michael, J. Dillon, \& A. E. J. Wals (Eds.), International Handbook of Research on Environmental Education (pp. 1-12). Routledge.

Stoll, K., Sørmo, W., \& Gårdvik, M. (2018). Sea Monsters Conquer the Beaches: Community Art as an Educational Resource. A marine debris project. In P. Leavy (Ed.), The Handbook of Arts-Based Research (chapter 24, pp. 455-476). Guilford Press.

Stoltenberg, U. (2020/2010). Kultur als Dimension eines Bildungskonzepts für eine nachhaltige Entwicklung [Culture as dimension of an educational concept for sustainable development]. Kulturelle Bildung online. https://www.kubi-online.de/artikel/kulturdimension-eines-bildungskonzepts-nachhaltige-entwicklung

Sund, L., \& Öhman, J. (2014). On the need to repoliticise environmental and sustainability education: rethinking the postpolitical consensus. Environmental Education Research, 20(5), 639-659. https://doi.org/10.1080/13504622.2013.833585

Sundberg, B., \& Ottander, C. (2014). Science in preschool - a foundation for education for sustainability? A view from Swedish preschool teacher education. In J. M. Davis \& S. Elliott (Eds.), Research in Early Childhood Education for Sustainability (chapter 17, pp. 280-293). Routledge.

Sørmo, W., Stoll, K., \& Gårdvik, M. (2013). The Abominable Snowman - Snow Sculpting as an interdisciplinary project in Norwegian teacher education. In T. Jokela, G. Coutts, M. Huhmarniemi, \& E. Härkönen (Eds.), Cool - Applied visual Arts in The North (pp. 158166). Erweko Oy.

Sørmo, W., Stoll, K., \& Gårdvik, M. (2018). Sjøuhyret - et tverrfaglig undervisningsopplegg om marin forsøpling innenfor utdanning for bærekraftig utvikling [The Seamonster - an interdisciplinary teaching programme about marine litter in the light of education for sustainable development]. In A. Pálsdóttir (Ed), Science competencies for the future (pp. 81-89). Proceedings of the 12th Nordic Research Symposium on Science Education, June 7th-9th 2017, Trondheim, Norway. http://nfsun.org/wpcontent/uploads/2018/05/NFSUN_PROCEEDINGS_2017-Final-1.pdf

Sørmo, W., Stoll, K., \& Kjelen, H. (2019). Stedsbasert læring [Place-based learning]. In Västerbottens museum och skribenterna (Eds.), Kulturlandskapet som undervisningsarena (part 2, pp. 101-117). Västerbottens museum. https://www.vbm.se/barn-skola/ny-bokkulturlandskapet-som-undervisningsarena/

Thornes, J. E. (2008). A Rough Guide to Environmental Art. Annual Review of Environment and Resources, 33, 391-411. https://doi.org/10.1146/annurev.environ.31.042605.134920 
Turmo, A., \& Østergaard, E. (2011). Levende realfag! [Living science!]. Norsk Pedagogisk Tidsskrift, 95(4), 243-246. https://doi.org/10.18261/ISSN1504-2987-2011-04-01

Udir (2019). Dybdelæring [In-depth learning]. Norwegian Directorate for Education and Training. https://www.udir.no/laring-og-trivsel/dybdelaring/

Udir (2020). Kunnskapsløftet 2020 [The national curriculum in Norway]. Norwegian Directorate for Education and Training. https://www.udir.no/lk20/overordnetdel/?lang=eng

UN (2015). Transforming our world: The 2030 agenda for sustainable development. Resolution adopted by the General Assembly. https://sdgs.un.org/2030agenda

UNEP (n.d.). Marine Litter: A Global Challenge. United Nations Environment Programme. https://www.unenvironment.org/resources/report/marine-litter-global-challenge-0

UNESCO (2005). United Nations Decade of Education for Sustainable Development 20052014: International implementation scheme. UNESDOC Digital Library. https://unesdoc.unesco.org/ark:/48223/pf0000139937

UNESCO (2015). UN Decade of Education for Sustainable Development (2005-2014). The DESD at a glance. http://unesdoc.unesco.org/images/0014/001416/141629e/pdf

Van Boeckel, J. (2013). At the Heart of Art and Earth. An Exploration of Practices in ArtsBased Environmental Education. Aalto University, School of Arts, Design and Architecture.

Van Manen, M. (1990). Researching Lived Experience. Human Science for an Action Sensitive Pedagogy. Albany: State University of New York Press.

Wals, A. E. J. (2012). Shaping the education of tomorrow: Report on the UN Decade of Education for Sustainable Development. UNESCO. https://unesdoc.unesco.org/ark:/48223/pf0000216606

Wals, A. E. J. (2015). Beyond unreasonable doubt. Education and learning for socioecological sustainability in the Anthropocene. Wageningen University.

Østergaard, E. (2013). Naturfag og kunst: berøringer med verden [Science and art: contacts with the world]. Bedre Skole, (4) 10-15.

https://www.utdanningsforbundet.no/upload/Tidsskrifter/Bedre\%20Skole/BS_4_2013/BS -0413-WEB_Ostergaard.pdf

Østern, T. P., \& Dahl, T. (2019). Performativ forskning. Sentrale teoretiske og analytiske begreper i boka [Performative research. Theoretical and analytical core concepts in the book]. In T. P. Østern, T. Dahl, A. Strømme, J. A. Petersen, A.-L. Østern, \& S. Selander (Eds.), Dybdelæring - en flerfaglig, relasjonell og skapende tilnærming (pp. 29-37). Universitetsforlaget. 